\title{
Long-term exposure of MCF-7 breast cancer cells to ethanol stimulates oncogenic features
}

\author{
ROBERT GELFAND ${ }^{1,3^{*}}$, DOLORES VERNET ${ }^{1,3^{*}}$, KEVIN W. BRUHN $^{2}$, SUREN SARKISSYAN $^{1}$, \\ DAVID HEBER $^{4}$, JAYDUTT V. VADGAMA ${ }^{1,2}$ and NESTOR F. GONZALEZ-CADAVID ${ }^{1-3}$ \\ ${ }^{1}$ Department of Medicine, Charles R. Drew University of Medicine and Science, Los Angeles, CA 90059; \\ ${ }^{2}$ David Geffen School of Medicine at UCLA, Los Angeles, CA 90095; ${ }^{3}$ Department of Surgery, \\ Los Angeles Biomedical Research Institute (LABioMed) at Harbor-UCLA Medical Center, \\ Torrance, CA 90502; ${ }^{4}$ Department of Medicine and Human Nutrition, \\ David Geffen School of Medicine at UCLA, Los Angeles, CA 90095, USA
}

Received July 19, 2016; Accepted October 10, 2016

DOI: $10.3892 /$ ijo.2016.3800

\begin{abstract}
Alcohol consumption is a risk factor for breast cancer. Little is known regarding the mechanism, although it is assumed that acetaldehyde or estrogen mediated pathways play a role. We previously showed that long-term exposure to $2.5 \mathrm{mM}$ ethanol (blood alcohol $\sim 0.012 \%$ ) of MCF-12A, a human normal epithelial breast cell line, induced epithelial mesenchymal transition (EMT) and oncogenic transformation. In this study, we investigated in the human breast cancer cell line MCF-7, whether a similar exposure to ethanol at concentrations ranging up to peak blood levels in heavy drinkers would increase malignant progression. Short-term (1-week) incubation to ethanol at as low as $1-5 \mathrm{mM}$ (corresponding to blood alcohol concentration of $\sim 0.0048-0.024 \%$ ) upregulated the stem cell related proteins Oct4 and Nanog, but they were reduced after exposure at $25 \mathrm{mM}$. Long-term (4-week) exposure to $25 \mathrm{mM}$ ethanol upregulated the Oct4 and Nanog proteins, as well as the malignancy marker Ceacam6. DNA microarray analysis in cells exposed for 1 week showed upregulated expression of metallothionein genes, particularly MT1X. Long-term exposure upregulated expression of some malignancy related genes (STEAP4, SERPINA3, SAMD9, GDF15, KRT15, ITGB6, TP63, and PGR, as well as the CEACAM, interferon related, and HLA gene families). Some of these findings were validated by RT-PCR. A similar treatment also modulated numerous microRNAs (miRs) including one regulator of Oct4 as well as miRs involved in oncogenesis and/or malignancy, with only a few estrogen-induced miRs.
\end{abstract}

Correspondence to: Dr Nestor F. Gonzalez-Cadavid, Department of Medicine, Charles R. Drew University of Medicine and Science, 1731 East 120th Street, Los Angeles, CA 90059, USA

E-mail: ncadavid@ucla.edu

*Contributed equally

Key words: MCF-7, alcohol, microRNAs, gene expression, stemness
Long-term $25 \mathrm{mM}$ ethanol also induced a 5.6-fold upregulation of anchorage-independent growth, an indicator of malignant-like features. Exposure to acetaldehyde resulted in little or no effect comparable to that of ethanol. The previously shown alcohol induction of oncogenic transformation of normal breast cells is now complemented by the current results suggesting alcohol's potential involvement in malignant progression of breast cancer.

\section{Introduction}

Excessive chronic alcohol intake is a widely acknowledged risk factor for breast cancer. In a previous study, we summarized the epidemiology and known pathology pertaining to alcohol consumption and breast cancer (1). Briefly, consumption of three or more drinks per day leads to a $40-50 \%$ increase in risk and there are $\sim 50,000$ alcohol-attributable breast cancer cases per year, worldwide (2-4). The risk of breast cancer increases with the quantity of alcohol consumed, showing a linear dose-response (5). There is a greater risk for lobular rather than ductal breast cancer (5-7), and tumors are more likely to be ER ${ }^{-}$and HER2 ${ }^{+}$in the women with high alcohol consumption $(8,9)$.

One proposed mechanism for the putative alcohol carcinogenicity involves stimulation of estrogen levels and/or estrogen responsiveness but other possibilities include effects unrelated to estrogen $(2,3,9-13)$ such as inhibition of DNA methylation, interaction with retinoid metabolism, or oxidative stress. Such changes could operate either by direct ethanol effects and/or through the first ethanol metabolite, acetaldehyde.

As summarized previously (1), a few studies in mice and rats have shown that ethanol consumption promotes mammary tumors via the estrogen pathway (14). The estrogen dependence was originally shown and partially explained in the widely used MCF-7 cell line, a human breast cancer luminal epithelial cell line which is estrogen and progesterone receptor positive and lacks ERBB2 gene amplification or Her2/neu protein overexpression (15-18). It was also shown that ethanol stimulates the in vitro growth, invasiveness and migration of 
these cells (17-24). However, the common denominator of the previous studies on MCF-7 cells is that the ethanol exposure was limited to $<1$ week, concentrations were $>50 \mathrm{mM}$, and the effects were modest. A similar situation occurred with studies conducted on other types of more malignant breast cancer cell lines, such as T47D and erbB2 transformed cells (25-30).

Another potential mechanism of ethanol's carcinogenicity is through enrichment of a subpopulation of cancer stem cells, but there are no reports on the effects of ethanol on this type of stem cells (31-33). Cancer stem cells are postulated to be involved in the generation of primary breast tumors and their progression to undifferentiated tumors and metastasis, and are claimed to be enriched within mammospheres $(34,35)$. Although ethanol affects the proliferation and differentiation of normal embryonic and adult stem cells $(36,37)$, it is not known whether it activates and/or increases the number of cancer stem cells. The latter process, as well as the regulation of breast cancer genes in general, is partially regulated by microRNAs (miR) $(34,38-41)$, particularly with regard to the epithelial mesenchymal transition (EMT) $(42,43)$. Ethanol affects the expression of certain miRs in alcoholic liver injury and other pathologies $(44,45)$, but no reports link this to breast cancer. In contrast, there is a substantial recent literature on miRs in relation to estrogen effects, particularly in MCF-7 cells (46-48), but none has been directly linked to ethanol exposure.

In our previous study on the non-malignant epithelial human breast cell line MCF-12A (1) we found that ethanol, but not acetaldehyde, induced oncogenic features and EMT, and stimulated the expression of a collection of mRNAs and miRs, including those associated with these processes, and also stimulated certain protein markers for stem-related properties.

In this study, the effects of short- and long-term exposures to physiologically relevant concentrations of ethanol, and acetaldehyde up to supraphysiological levels were studied using MCF-7 monolayers and mammospheres. Stem cell markers, global transcriptional gene expression signatures including miRs, and in vitro responses in oncogenic assays were carried out to better understand the mechanism of action of alcohol on malignant progression in breast cancer. The aim was to clarify: a) whether the epidemiological relationship between excessive and long-term alcohol consumption and the malignant progression of breast cancer can be elucidated by defining the effects of ethanol on an accepted epithelial breast cancer cell line such as MCF-7 in vitro; b) whether ethanol intensifies some of the MCF-7 malignant features in a dosage- and/or duration of exposure-dependent way; $\mathrm{c}$ ) the potential mediation of these effects by stem cell enrichment in both monolayers and mammospheres; d) the possible role of acetaldehyde in mediating those changes; and e) the impact of both alcohol and acetaldehyde on the mRNA and miR global signatures, so as to define the more affected pathways and to evaluate putative estrogen mediation.

\section{Materials and methods}

Cell culture. The human adherent epithelial adenocarcinoma MCF-7 cell line was obtained from ATCC (Catalog HT-22 ${ }^{\mathrm{TM}}$ Manassas, VA, USA), and routinely cultured on monolayers at $\leq 80 \%$ confluence in MEME (minimum essential medium Eagle's, ATCC), $10 \% \mathrm{FBS}$ and $0.01 \mathrm{mg} / \mathrm{ml}$ bovine insulin
(Sigma, St. Louis, MO, USA). For most experiments, cells were incubated on 6-well plates with 0-25 mM ethanol (Fisher, molecular grade ethanol) or 0-12.5 mM acetaldehyde (Sigma, ACS), using freshly prepared solutions. Medium was replaced 2-3 times/week, including addition of ethanol or acetaldehyde, and cultures were maintained for 1 week (short-term incubations), or for 4 weeks (long-term incubations). In the latter case, cells were passaged on average once a week, with a 1:3 splitting.

Mammospheres were generated for 1 week experiments by seeding 50,000 cells onto Corning Ultra Low Attachment 6-well-plates with $2 \mathrm{ml} /$ well of MEBM medium (Fisher, mammary epithelial cell growth medium), adding $2 \%(\mathrm{v} / \mathrm{v})$ of B27 Supplement (B27 serum-free supplement, Invitrogen, Carlsbad, CA, USA) and $0.01 \mathrm{mg} / \mathrm{ml}$ bovine insulin, and then adding ethanol or acetaldehyde. For 4-week incubations, monolayers were cultured for this period with ethanol or acetaldehyde and used for mammosphere generation that were maintained in the presence of these agents for an additional week. Their number and total area were determined by applying quantitative image analysis (QIA) to digital photographs taken with a Nikon digital camera of $0.005 \%$ crystal violet stained mammospheres contained in individual wells of a 6-well plate, using ImagePro-Plus 5.1 software (Media Cybernetics, Silver Spring, MD, USA). After images were calibrated for background lighting, integrated optical density (IOD $=$ area $\mathrm{x}$ average intensity) was calculated. Inverted microscopy images were taken under phase contrast at $40 \mathrm{X}$ and 100X using a Nikon Eclipse Ti microscope and a Leica VCC digital camera.

Western blot analyses. Medium was decanted from wells and cells were washed twice with PBS at $\mathrm{pH}$ 7.4. Boiling buffer (1\% SDS, $1 \mathrm{mM}$ sodium orthovanadate, $10 \mathrm{mM}$ Tris $\mathrm{pH} 7.4$ and protease inhibitors) was added to each well, cells were scraped from each well and passed several times through a 26-gauge needle to reduce viscosity, incubated in a boiling water bath for $5 \mathrm{~min}$, and centrifuged at 16,000 $\mathrm{g}$ for $5 \mathrm{~min}$, then $20-40 \mu \mathrm{g}$ of protein was run on $4-15 \%$ gradient polyacrylamide gels, transferred electrophoretically to nitrocellulose, and analyzed by immunodetection using antibodies against: i) Oct-4, (rabbit polyclonal, 1:500, BioVision, Mountain View, CA, USA); ii) CEACAM-6 (rabbit polyclonal, 1:500, Novus Biologicals, Littleton, CO, USA); iii) NANOG (rabbit polyclonal, 1:1,000, AVIVA Systems, San Diego, CA, USA) and iv) GAPDH (mouse monoclonal, 1:3,000, Chemicon). Membranes were incubated with secondary polyclonal horse anti-mouse or anti-rabbit IgG linked to horseradish peroxidase (1:2,000; BD Transduction Laboratories, Franklin Lakes, NJ, USA or 1:5,000; Amersham GE, Pittsburgh, PA, USA), bands were visualized with luminol (SuperSignal West Pico, Chemiluminescent, Pierce, Rockford, IL, USA). For the negative controls the primary antibody was omitted.

Immunocytochemistry. Cultures were grown in 8-wellremovable-chamber slides, subjected to immunofluorescence detection by quenching in $0.3 \% \mathrm{H}_{2} \mathrm{O}_{2}$, blocking with goat (or corresponding) serum, and incubated overnight at $4^{\circ} \mathrm{C}$ with the primary antibody for Oct- 4 or NANOG. This was followed by a secondary anti-mouse IgG biotinylated antibody (goat, 
1:200, Vector Laboratories) and this complex was detected with streptavidin-Texas Red. After washing with PBS, the sections were mounted with Prolong antifade/DAPI (Molecular Probes, Carlsbad, CA, USA). Negative controls in all cases omitted the first antibodies or were replaced by $\mathrm{IgG}$ isotype.

Flow cytometry. Control and $25 \mathrm{mM}$ ethanol-incubated MCF-7 cells were grown in GM-20, washed twice with Hanks buffered salt solution, disaggregated by repeated pipeting in CellStripper (Mediatech, Manassas VA, USA), pelleted, and resuspended in staining buffer consisting of PBS, 3\% FBS (SB). Cells were incubated in the presence of antibodies for $30 \mathrm{~min}$ on ice, washed twice with SB, and resuspended in SB for flow cytometry on an LSR II (BD Biosciences). Controls included samples without any antibody as well as samples including all combinations of antibodies so as to determine that the Ceacam6 stained cells and the CD44 stained cells were accurately identified. Data analysis and plotting were done using FACSDiva Version 6.1.1 software. Fluorophore-conjugated antibodies and G12-5841 PE (eBiosciences), performed separately, followed cell permeabilization with BD CytoFix/ CytoPerm kit. BD CompBeads were used for compensation.

Global DNA microarray transcriptional profile. RNA was isolated from cells using the RNeasy Plus Micro kit (Qiagen) with quality determined using the Agilent 2100 Bioanalyzer. Assays were performed by the UCLA DNA microarray core, applying the Affymetrix Human Gene 1.0 ST array for $>30,000$ genes. Up- and downregulated genes (by >2-fold) were considered, except where indicated. DNA microarray results are deposited in the GEO library under accession no. GSE72013.

$R T / P C R$. The expression of some of the down- and upregulated genes identified by DNA microarray analysis was further examined on triplicate RNA samples. cDNA was synthesized by reverse transcription using the Superscript III First-Strand Synthesis SuperMix for qRT-PCr (Life Technologies), and the resulting samples were amplified using PCR. Primers were designed using the NCBI Primer Blast program applied to mRNA sequences and synthesized by Sigma-Aldrich. All primers were designed to include an exon-exon junction except for GAPDH. Negative controls omitted cDNA. PCR results were analyzed by electrophoresis through $1 \%$ agarose gels in Tris-acetate EDTA buffer followed by photography under ultraviolet illumination in a UVP Biodoc transilluminator.

Global miR profiles. RNA was isolated from cells using the mirVana $^{\mathrm{TM}}$ miRNA isolation kit (Ambion), and analysis was carried out by LC Sciences (Houston, TX, USA) for all miR transcripts listed in the Sanger miRBase Release 18.0. The miR results are deposited in the GEO library under accession no. GSE72013.

Anchorage-independence. Cells were trypsinized, suspended in $1 \mathrm{ml} /$ well of warm $\left(37^{\circ} \mathrm{C}\right) 0.3-0.5 \%$ agar in MEME$10 \%$ FBS-bovine serum albumin (soft agar layer) and 10,000 cells $/ \mathrm{ml}$ were plated in duplicate or triplicate above a layer of $1 \mathrm{ml}$ of $1 \%$ agar in the same medium that had previously been allowed to solidify on 6 -well plates at $4^{\circ} \mathrm{C}$ (hard layer agar). Cultures were allowed to grow for 3-4 weeks and when foci were visible, they were stained with $0.005 \%$ crystal violet in Hanks solution for $1 \mathrm{~h}$, wells were photographed as described in 'Cell culture', and colonies were counted, also as described above.

Cell invasiveness. Matrigel ${ }^{\mathrm{TM}}$ basement membrane matrix was diluted 1:5 with serum free culture medium containing $0.5 \%$ BSA according to the manufacturer's instructions. Trypsinized cells were added at 25,000 cells/well to Transwell ${ }^{\circledR}$ Permeable Support 8.0- $\mu \mathrm{m}$ inserts containing Matrigel and culture medium, and cultured in a 24-well plate using FBS as the chemoattractant for $40 \mathrm{~h}$. Cells were fixed and stained with $0.5 \%$ toluidine blue.

Response to tamoxifen. MCF-7 cells (control vs 4 weeks $25 \mathrm{mM}$ ethanol) were incubated in estrogen-depletion medium (EDM): phenol red-free DMEM/F12 (Invitrogen) containing $5 \%$ charcoal stripped fetal bovine serum (Gibco) for 3 days, washed with Hanks, trypsinized, resuspended in EDM and plated at 1,000 cells/well into a 96-well plate. 4-OH-tamoxifen was added to a concentration of $0,1,2,5$ or $10 \mu \mathrm{M}$ (6-wells for each concentration). Cells were incubated at $37^{\circ} \mathrm{C}$ in $5 \% \mathrm{CO}_{2}$ for 4 days, washed once with Hanks, followed by the addition of $100 \mu \mathrm{l}$ of EDM. After 30-min additional incubation, each well received $20 \mu \mathrm{l}$ of the metabolic activity indicator CellTiter $96^{\circledR}$ AQueous One Solution Cell Proliferation assay (Promega, Madison, WI, USA), and cells were further incubated $\left(37^{\circ} \mathrm{C}\right.$ in $\left.5 \% \mathrm{CO}_{2}\right)$ for $30 \mathrm{~min}$. The absorbance at $490 \mathrm{~nm}$ was measured using an automated plate reader.

Statistical analyses. Statistical values are expressed as the mean $( \pm$ SEM). The normality distribution of the data was established using the Wilk-Shapiro test. Multiple comparisons were analyzed by a single factor ANOVA, followed by post hoc comparisons with the Newman-Keuls test. Differences among groups were considered statistically significant at $\mathrm{p}<0.05$.

\section{Results}

Short-term exposure of MCF-7 monolayers to low concentrations of ethanol. To investigate the possibility that ethanol exerts its oncogenic effects through the stimulation of cancer stem cell proliferation, we carried out experiments to ascertain the effects on the key stem cell marker proteins Oct 4 and Nanog. MCF-7 monolayer cultures were incubated at 30-80\% confluence for 7 days with $1-25 \mathrm{mM}$ ethanol and subjected to western blot analysis for Oct4 and Nanog (Fig. 1). The highest concentration of ethanol is roughly equivalent to peak serum levels of alcohol in women within $1 \mathrm{~h}$ of consumption of 3-4 glasses of wine. The stemness-related nuclear Oct4a isoform (45 kDa) was increased after exposure to 1 and $5 \mathrm{mM}$ ethanol, and was reduced at 10 and $25 \mathrm{mM}$. Triplicate samples of the $25 \mathrm{mM}$ treatment show downregulation. The cytoplasmic Oct4b (33 kDa), unrelated to stemness, was expressed at low levels and remained unchanged. The main $39 \mathrm{kDa}$ Nanog isoform was increased after exposure to 1-10 $\mathrm{mM}$ ethanol, and analogous to the Oct 4 result, was also decreased at $25 \mathrm{mM}$. The nuclear localization of Oct4a, consistent with its known stemness function, and, in addition, the nuclear localization of Nanog, were confirmed by double immunofluorescence 


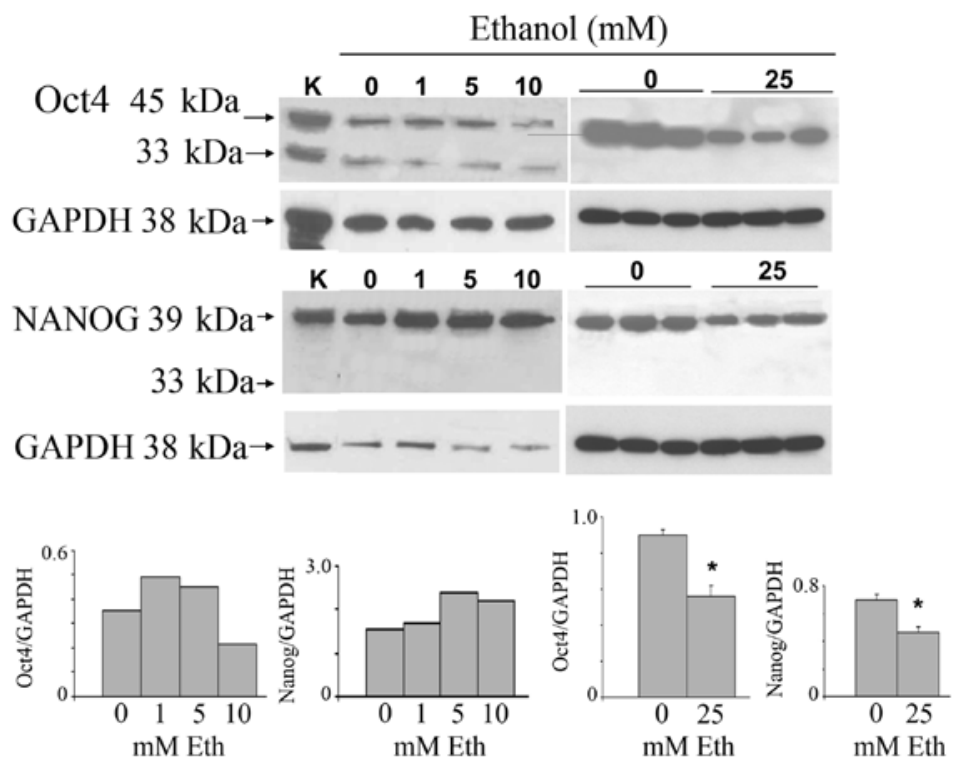

Figure 1. Dose response of exposure of MCF-7 cells to ethanol for 1 week. Extracts from the monolayer cultures on 6-well plates, incubated at the indicated ethanol concentrations for 1 week, were analyzed by western blot analysis and corrected for GAPDH expression. Rat kidney protein was used as a positive control and is labeled as K. Top left, dose course to $10 \mathrm{mM}$ for Oct $4 \mathrm{a}(45 \mathrm{kDa})$ and Nanog $(39 \mathrm{kDa})$, with GAPDH as reference. Top right, 0 and $25 \mathrm{mM}$ only, in triplicate incubations for both control and $25 \mathrm{mM}$ ethanol-treated samples. Bottom, densitometric determinations; ${ }^{*} \mathrm{p}<0.05$.

Table I. The non-malignant cell line MCF-12A is compared to the malignant cell line MCF-7 in an oncogenic signature (column 3). ${ }^{\mathrm{a}}$

\begin{tabular}{|c|c|c|c|c|c|c|}
\hline \multirow[b]{2}{*}{ Gene } & \multirow[b]{2}{*}{ Gene description } & \multirow{2}{*}{$\begin{array}{c}\text { Oncogenic signature } \\
\text { C/C } \\
\text { MCF-7/MCF-12A }\end{array}$} & \multicolumn{2}{|c|}{1 week } & \multicolumn{2}{|c|}{4 weeks } \\
\hline & & & $\begin{array}{c}\mathrm{C} \\
\mathrm{MCF}-7\end{array}$ & $\begin{array}{c}\text { Eth/C } \\
\text { MCF-7 }\end{array}$ & $\begin{array}{c}\mathrm{C} \\
\mathrm{MCF}-7\end{array}$ & $\begin{array}{r}\text { Eth/C } \\
\text { MCF-7 }\end{array}$ \\
\hline CEACAM5 & CEA related cell adhesion molecule & 42.20 & 181 & 1.03 & 223 & 3.14 \\
\hline$P G R$ & Progesterone receptor & 12.80 & 137 & 0.98 & 494 & 1.71 \\
\hline ESRI & Estrogen receptor 1 & 10.10 & 111 & 0.82 & & 0.88 \\
\hline TET2 & Tet oncogene family member 2 & 9.87 & 392 & 1.08 & 881 & 1.28 \\
\hline$B C A S 1$ & Breast carcinoma amplified sequence 1 & 8.69 & 161 & 1.38 & 528 & 1.08 \\
\hline CEACAM6 & CEA related cell adhesion molecule 6 & 8.03 & 121 & 1.15 & 170 & 2.95 \\
\hline ERBB3 & v-erb-b2 erythro leukemia homolog 3 & 7.95 & 766 & 1.11 & 816 & 1.14 \\
\hline TACSTDI & Tumor associated Ca signal transducer 1 & 7.91 & 2,715 & 1.02 & 3,386 & 1.06 \\
\hline$B C A S 2$ & Breast ca amplified seq 2 & 7.31 & 3,697 & 1.12 & 4,533 & 0.97 \\
\hline$M Y B$ & $\mathrm{v}$-myb oncogene homolog & 6.40 & 474 & 1.33 & 700 & 1.16 \\
\hline TET1 & Tet oncogene 1 & 5.01 & 116 & 1.29 & 147 & 0.78 \\
\hline TOB1 & Transducer of ERBB2 1 & 3.42 & 4,246 & 1.18 & 3,498 & 1.01 \\
\hline$B C A S 3$ & Breast carcinoma amplified seq 3 & 3.34 & 1,426 & 1.07 & 1,359 & 1.11 \\
\hline$E R B B 2$ & v-erb-b2 oncogene homolog 1 & 2.53 & 723 & 1.10 & 437 & 1.17 \\
\hline$A R$ & Androgen receptor & 2.41 & 248 & 1.26 & 71 & 0.98 \\
\hline MTSS1 & Metastasis suppressor 1 & 0.27 & 285 & 1.03 & 171 & 1.17 \\
\hline$C D 44$ & CD44 molecule (Indian blood group) & 0.23 & 591 & 0.99 & 492 & 1.23 \\
\hline$C T G F$ & Connective tissue growth factor & 0.13 & 205 & 0.76 & 86 & 0.96 \\
\hline
\end{tabular}

${ }^{\text {a} E x p o s u r e ~ o f ~ M C F-7 ~ t o ~ e t h a n o l ~ a t ~} 1$ week (column 5) and 4 weeks (column 7) are shown. Gene IDs as NCBI Gene data set. C, normalized DNA microarray values for gene expression in untreated cells. Eth, ethanol treated.

with Texas red for the specific antigen and DAPI for nuclei in MCF-7 cells incubated in the absence of ethanol (data not shown).
In order to investigate whether ethanol effects are mediated by its first oxidation product, acetaldehyde, a range of acetaldehyde concentrations was applied to MCF-7 monolayers and 
mM Acetaldehyde
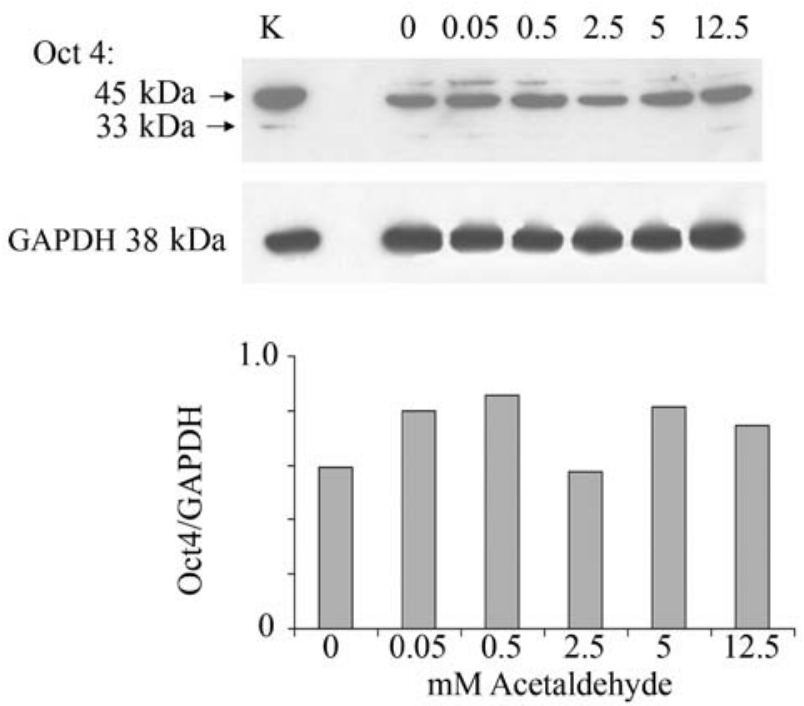

Figure 2. MCF-7 cells grown in monolayer were subjected to acetaldehyde over the range of $0-12.5 \mathrm{mM}$ for 1 week. Oct 4 was analyzed by western blot analysis. The stem cell active upper band Oct4a and the non-stem-active lower band Oct $4 \mathrm{~b}$ are shown. Lower, Oct4a values were normalized according to GAPDH prevalence. $\mathrm{K}$, rat kidney extract as positive marker for Oct 4 .

the effect on Oct4 expression was analyzed. Acetaldehyde over the range of $0.5-12.5 \mathrm{mM}$ and over the same time of incubation did not affect the expression of Oct4 (Fig. 2). These acetaldehyde concentrations, considerably lower than the respective ethanol concentrations, were chosen based on the fact that they are marginally to considerably higher (i.e., approximately one log value) than the acetaldehyde values that would be expected in human serum after substantial drinking. These levels have been measured to be as much as $0.2 \mathrm{mM}$ (49). Even at these levels acetaldehyde had little or no effect on Oct4 levels.

Ethanol exposure affects gene expression both in the shortterm and long-term. Gene expression analysis of MCF-7 cells grown in monolayer in the presence or absence of ethanol (25 $\mathrm{mM}$ ) for 1 and 4 weeks was carried out by subjecting RNA samples to DNA microarray analysis using the Affymetrix Human Gene 1.0 ST system. The longer exposure was intended to better model the situation that exists in vivo in chronic drinkers. In order to determine the global transcriptional signature that differentiates the malignant MCF-7 cells from a normal counterpart, we compared the MCF-7 cell line with the spontaneously immortalized but otherwise benign breast epithelial line MCF-12A (1). For each gene sequence, the ratio of MCF-7 expression to $\mathrm{MCF}-12 \mathrm{~A}$ expression was determined from duplicate samples. We refer to the collection of MCF-7/MCF-12A gene expression ratios shown in Table I as the MCF-7 oncogenic signature. Some genes related to oncogenic processes were substantially changed, being up- or downregulated by a factor $\geq 2.0$. This transcriptional signature was characterized by 15 genes upregulated by a factor $\geq 2.4$, and 3 oncogenesis-related genes downregulated to a factor of $\leq 0.27$, including some associated with oncogenic transformation and some associated with growth-related hormone receptors.
Table II. Expression of stem-related genes after 1 week of ethanol or acetaldehyde. ${ }^{\text {a }}$

\begin{tabular}{|c|c|c|c|}
\hline \multirow[b]{2}{*}{ Gene } & \multicolumn{3}{|c|}{ Monolayers with ethanol } \\
\hline & Control & $25 \mathrm{mM}$ Eth & Eth/cont \\
\hline OCT-4A & 150 & 144 & 0.96 \\
\hline NANOG & 79 & 70 & 0.89 \\
\hline ALDH2 & 167 & 149 & 0.89 \\
\hline SOX4 & 484 & 475 & 0.98 \\
\hline HEY1 & 109 & 112 & 1.03 \\
\hline JAG1 & 185 & 191 & 1.03 \\
\hline DNER & 124 & 108 & 0.87 \\
\hline \multirow[t]{2}{*}{ DLL1 } & 259 & 248 & 0.96 \\
\hline & \multicolumn{3}{|c|}{ Mammospheres with ethanol } \\
\hline Gene & Control & $25 \mathrm{mM}$ Eth & Eth/cont \\
\hline OCT-4A & 116 & 136 & 1.17 \\
\hline NANOG & 75 & 77 & 1.03 \\
\hline ALDH2 & 124 & 147 & 1.19 \\
\hline SOX4 & 450 & 446 & 0.99 \\
\hline HEY1 & 82 & 95 & 1.16 \\
\hline JAG1 & 178 & 176 & 0.99 \\
\hline DNER & 91 & 99 & 1.09 \\
\hline \multirow[t]{2}{*}{ DLL1 } & 248 & 268 & 1.08 \\
\hline & \multicolumn{3}{|c|}{ Monolayers with acetaldehyde } \\
\hline Gene & Control & $25 \mathrm{mM}$ Acet & Acet/cont \\
\hline OCT-4A & 76 & 85 & 1.12 \\
\hline NANOG & 38 & 42 & 1.11 \\
\hline ALDH2 & 88 & 105 & 1.19 \\
\hline SOX4 & 544 & 558 & 1.03 \\
\hline HEY1 & 69 & 78 & 1.13 \\
\hline JAG1 & 168 & 202 & 1.20 \\
\hline DNER & 79 & 87 & 1.10 \\
\hline DLL1 & 253 & 267 & 1.06 \\
\hline
\end{tabular}

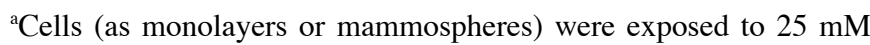
ethanol or $2.5 \mathrm{mM}$ acetaldehyde, or received no added treatment (control). Upregulation and downregulation induced by ethanol or acetaldehyde is expressed as the ratio of treated expression value divided by control.

We then investigated whether an oncogenic signature reflected the effects of ethanol treatment on MCF-7 by itself. Short-term ethanol incubation for 1 week had little or no effect on the expression of this group of 18 genes (Table I), whereas 4-week exposure increased CEACAM5, CEACAM6, and progesterone receptor (PGR) gene expression (Table I). Neither 1-nor 4-week exposures to ethanol or acetaldehyde affected the transcriptional expression of Oct-4 or Nanog (Table II). 
A

Oct4 $45 \mathrm{kDa}$

GAPDH $38 \mathrm{kDa}$

B

Nanog $39 \mathrm{kDa}$

GAPDH $38 \mathrm{kDa}$

C

Ceacam6 $\quad 42 \mathrm{kDa}$

GAPDH $\quad 38 \mathrm{kDa}$

D

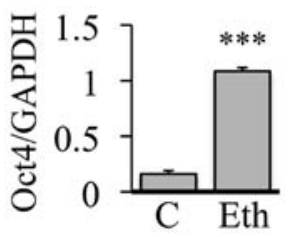

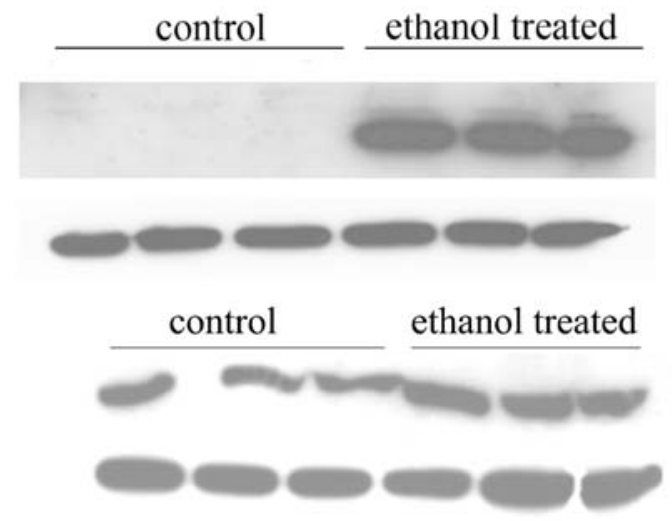

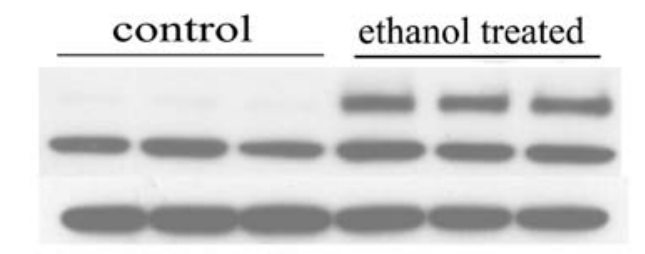

E

F

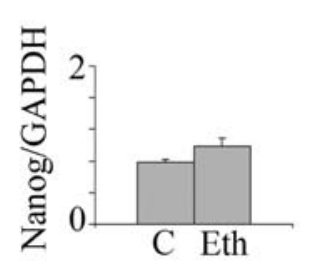

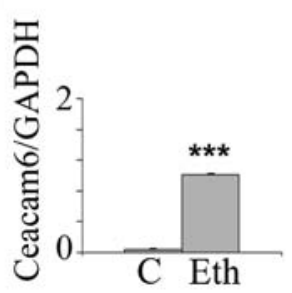

Figure 3. Long-term exposure of MCF-7 cells to ethanol at $25 \mathrm{mM}$ increases Oct4a, Nanog, and Ceacam6 protein expression. Triplicate samples (control vs. $25 \mathrm{mM}$ ethanol) grown as monolayer cultures on 6-well plates, incubated for 4 weeks, were analyzed by western blot analysis, and densitometric scans were corrected for GAPDH expression. (A) expression of Oct4a (45 kDa). (B) Nanog (39 kDa). (C) Ceacam6 (42 kDa), all with GAPDH as reference. Densitometric determinations for proteins normalized by Gapdh as (D) Oct4; (E) Nanog; (F) Ceacam6; *** p<0.001.

Upregulation of stem-related proteins and Ceacam6 protein. In view of the interesting results on the transcriptional expression of the malignancy related CEACAMs, we evaluated by western blot analysis the effects of long-term ethanol exposure on Ceacam6, an oncogenic protein associated with breast cancer (50), along with the Oct4 and Nanog proteins. Fig. 3 shows that $25 \mathrm{mM}$ ethanol upregulates the expression of these proteins, with particularly strong upregulation in Oct4 and Ceacam6, and a visible but non-significant increase of Nanog. In the case of Oct4, this suggests a post-transcriptional modulation induced by ethanol (see Discussion). These results potentially may also indicate the induction of higher stem cell number or the selection of a subpopulation of cells with some stem-like features.

In order to determine whether Ceacam- 6 upregulation represented a global increase or was restricted to a subpopulation of cells, untreated control MCF-7 monolayers and monolayer cells exposed to $25 \mathrm{mM}$ ethanol for 4 weeks were analyzed by flow cytometry. Fig. 4 (center) shows that a fraction of the cells did show enrichment of Ceacam- 6 following ethanol treatment, from $2.11 \%$ in controls to $8.18 \%$ in ethanoltreated cells, consistent with levels of upregulation observed in western blot analyses and PCRs. The control forward- and side-scattering (Fig. 4, left) indicate that the ethanol treatment did not appreciably affect cell size or internal complexity, as shown by the lack of observed changes.
Long-term ethanol upregulates Ceacam6 protein in mammospheres, but does not induce an increase in Oct4 or Nanog proteins. In view of the assumption that mammospheres are enriched in stem cells, we investigated whether ethanol affects mammosphere formation and composition. MCF-7 cells were maintained in monolayer culture in the presence or absence of ethanol, following which mammospheres were prepared from each sample. The mammospheres derived from control and ethanol treated cultures were maintained for an additional week in control medium or ethanol medium respectively. The number of mammospheres and their morphology did not visually appear to be modified by ethanol exposure (data not shown).

Despite the observed increase in Oct4a and Nanog proteins induced by long-term $25 \mathrm{mM}$ ethanol treatment in MCF-7 monolayers, it is of interest that these effects were not replicated in mammospheres obtained from these cultures and maintained for an additional week in the presence of ethanol. Fig. 5 shows that the previously observed increase in Oct4a and Nanog in monolayer was not observed in mammospheres where stem cells should be enriched, but Ceacam6 did remain upregulated. More surprisingly, taking into account our original assumption, when mammospheres were quantitated by determining both size and number, long-term exposure to ethanol did not significantly increase their yield, as judged by their relative area (29,352 control vs. 33,889 ethanol-treated), 

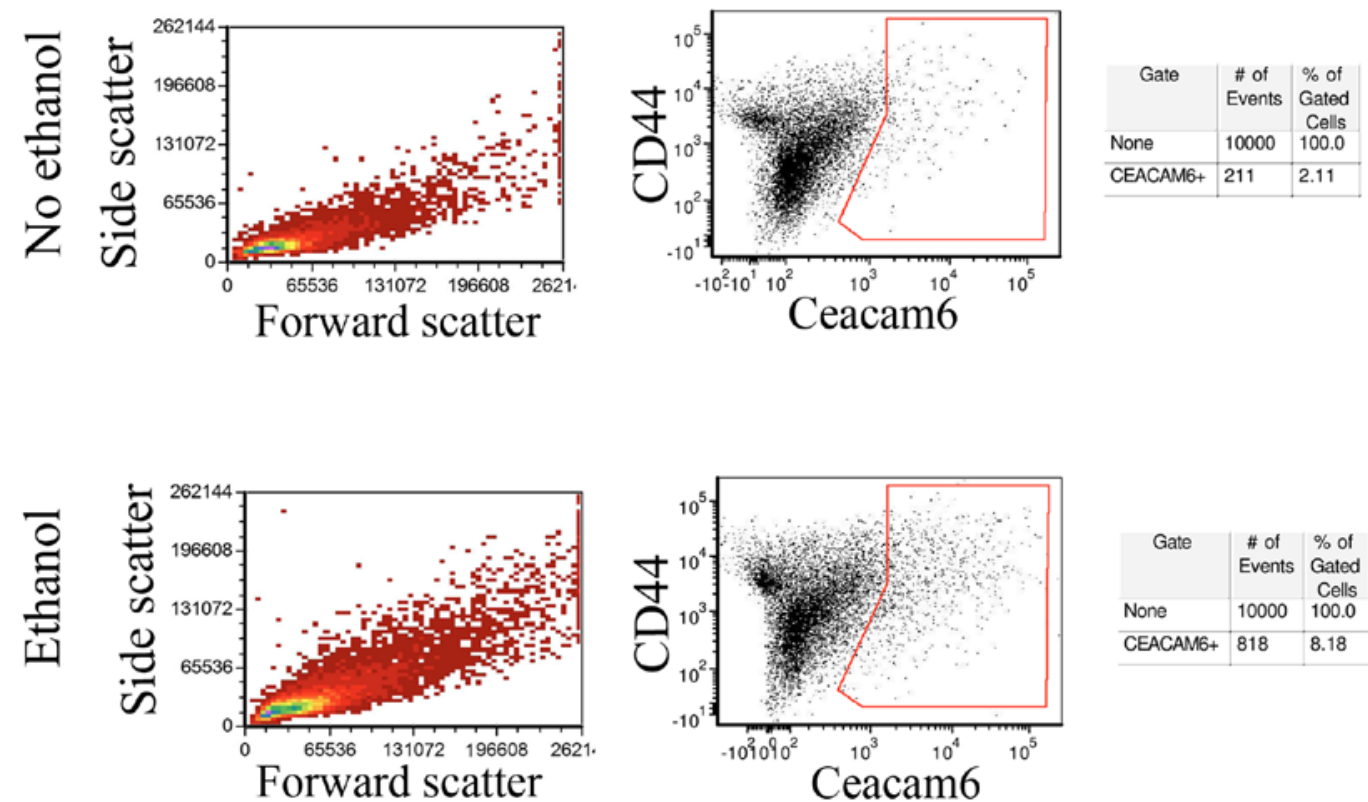

Figure 4. Flow cytometry shows an enrichment of CEACAM6 expressing cells following long-term $25 \mathrm{mM}$ ethanol exposure. MCF-7 monolayers incubated 4 weeks with $25 \mathrm{mM}$ ethanol and their untreated controls were subjected to flow cytometry. Left panels, side scatter vs. forward scatter. Center panels, CD44 vs. Ceacam6 labeling. In the Ceacam6 vs. CD44 panels, the control (no ethanol treatment) sample showed 2.11\% of the sample cells in the Ceacam6 positive group (box). The ethanol-treated sample showed a total of $8.18 \%$ of cells as positive for Ceacam6 (box). Right panels, counts of total cells in each sample as well as the number of cells showing Ceacam6 positive fluorescence.
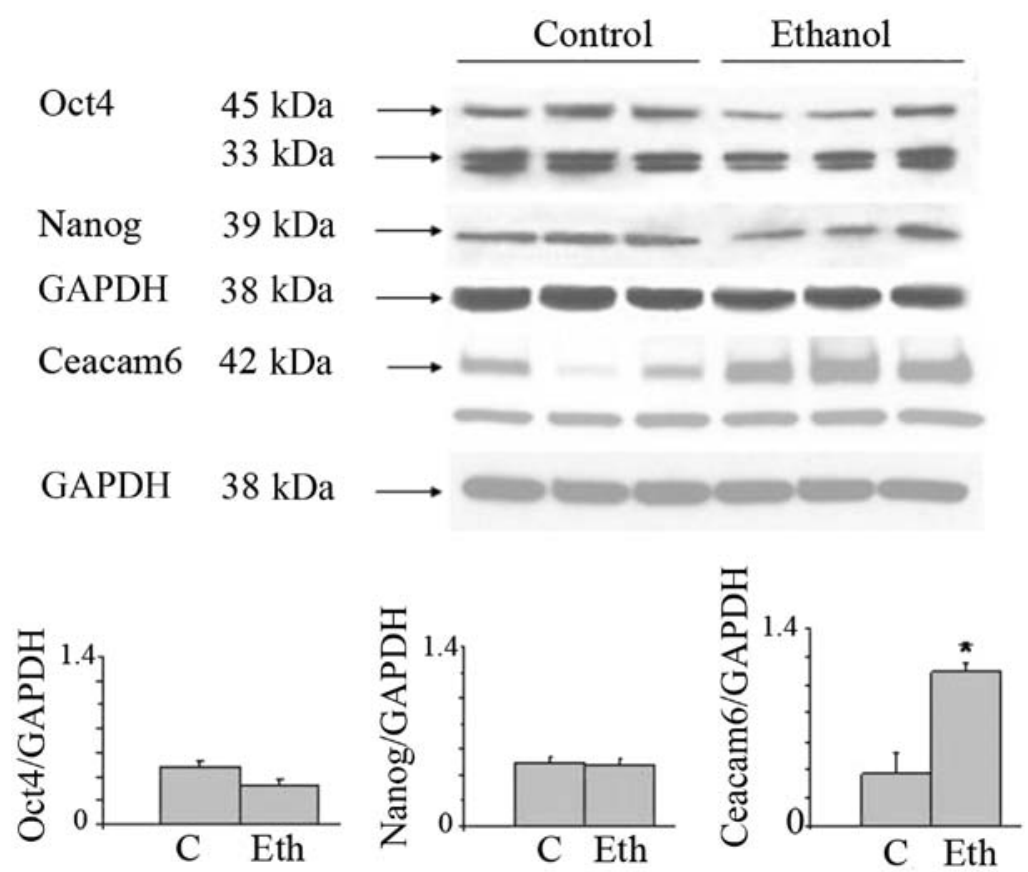

Figure 5. The increased expression of Oct4a, Nanog, and Ceacam6 proteins found in MCF-7 monolayers upon long-term exposure to ethanol is considerably reduced or disappears in mammospheres. Mammospheres were obtained as described and then further incubated for 1 week in the presence or absence of $25 \mathrm{mM}$ ethanol and were analyzed by western blot analysis and corrected for GAPDH expression. Top, expression of Oct4a (45 kDa), Nanog (39 kDa); and Ceacam6 (42 kDa), with GAPDH as reference. Bottom, densitometric determinations; ${ }^{*} \mathrm{p}<0.05$.

or by their numbers either by counting stained mammospheres under the microscope (1,337 control vs. 1,295 ethanol) or as determined using quantitative image analysis (1,314 control vs. 1,357 ethanol-treated).

RNA was isolated from the mammospheres obtained under 1-week exposure to ethanol or acetaldehyde and subjected to DNA microarray analysis. Table II shows that mammospheres were not enriched in the expression of a collection of stem cell genes. Neither ethanol nor acetaldehyde stimulated the expression of these genes in mammospheres or their original monolayers, which is noteworthy since some are related to breast cancer, such as: $A L D H 2, S O X 4, S O X 2, K L F 4, L I N 28$, HEY1, JAG1, DNER or Dll1 (51). No parallel assay was conducted in the mammospheres exposed long-term to ethanol. 
Table III. Some gene families upregulated after long-term $25 \mathrm{mM}$ ethanol.

\begin{tabular}{|c|c|c|c|}
\hline Gene ID & Gene Description & $\mathrm{C}$ & Eth/C \\
\hline Ceacam5 & Carcinoembryonic antigen-related cell adhesion molecule 5 & 223 & 3.14 \\
\hline Ceacam6 & Carcinoembryonic antigen-related cell adhesion molecule 6 & 170 & 2.95 \\
\hline Ceacam7 & Carcinoembryonic antigen-related cell adhesion molecule 7 & 70 & 1.9 \\
\hline Ceacaml & Carcinoembryonic antigen-related cell adhesion molecule 1 & 43 & 1.9 \\
\hline IFI6 & Interferon, $\alpha$-inducible protein 6 & 333 & 8.1 \\
\hline IFITMI & Interferon-induced transmembrane protein 1 & 624 & 2.4 \\
\hline IRF9 & Interferon regulatory factor 9 & 119 & 1.8 \\
\hline IL24 & Interleukin 24 & 164 & 2.1 \\
\hline$H L A-A$ & Major histocompatibility complex, Class I,A & 914 & 1.8 \\
\hline$H L A-B$ & Major histocompatibility complex, Class I,B & 937 & 1.9 \\
\hline$H L A-C$ & Major histocompatibility complex, Class I,C & 1,237 & 1.8 \\
\hline$H L A-G$ & Major histocompatibility complex, Class I,G & 518 & 1.7 \\
\hline$H L A-H$ & Major histocompatibility complex, Class I,H & 561 & 1.8 \\
\hline
\end{tabular}

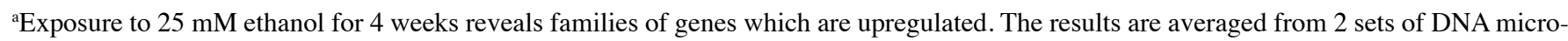
array assays. C, normalized DNA microarray values for gene expression in untreated cells. Eth/C, ratio of DNA microarray gene expression values for ethanol-treated vs. control cells.

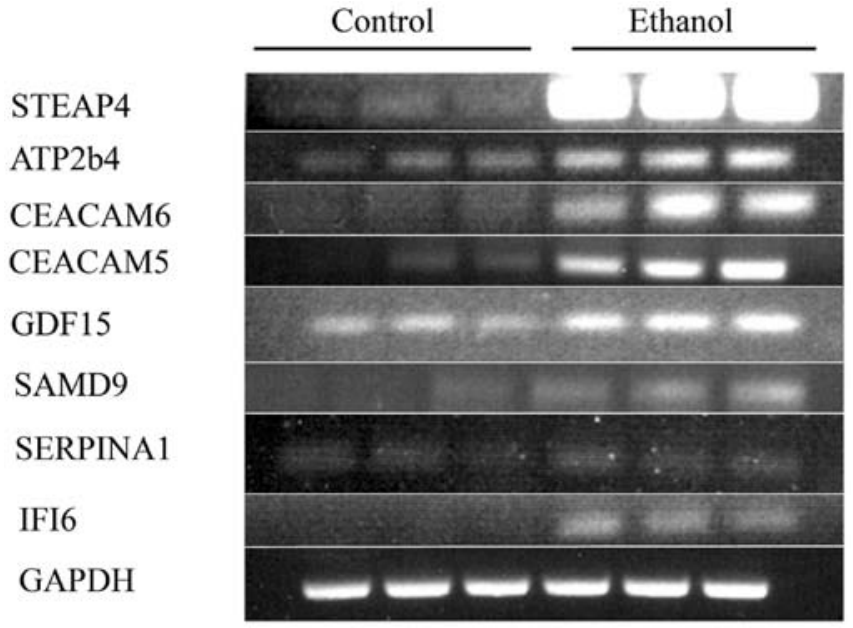

Figure 6. Long-term exposure to $25 \mathrm{mM}$ ethanol increases the transcriptional expression of several oncogenic genes different from the ones in the MCF-7/ MCF-12A comparative signature. Confirmation for some selected genes from one of two experiments. PCRs of the selected gene products (triplicate controls vs. triplicate $25 \mathrm{mM}$ ethanol-treated) were run on separate gels.

Gene expression in MCF-7 after ethanol exposure. As stated above, CEACAM6 protein upregulation induced by long-term ethanol exposure as shown on western blot analyses was in general agreement with mRNA upregulation, so we investigated whether other CEACAM mRNAs or those from other gene families were also upregulated. Table III shows that gene expression of the CEACAMs, cytokines and HLAs were all stimulated by $25 \mathrm{mM}$ ethanol, by factors ranging from 1.7 to 8.1 .

Long-term incubation with ethanol also induces other changes of oncogenic relevance, as confirmed by the substantial upregulation of a series of genes related to breast cancer such as STEAP4, SERPINA3, SAMD9, GDF-15, TP63, PGR, and others, with the transcriptional expression of 13 genes being increased $\geq 2.0$ in two experiments (Table IVA). To confirm the DNA microarray results, selected RNAs from the second of the two experiments were subjected to RT-PCR for some genes in the families mentioned above (Fig. 6). The correspondence between the RT-PCR and DNA microarray values was good to excellent (Table IVB), thus showing that ethanol indeed upregulated these cancer-related genes, and validating in general the DNA microarray data.

Of particular interest, a family of genes, the metallothioneins (MTs), is known to be induced by ethanol $(52,53)$. Short-term $25 \mathrm{mM}$ ethanol upregulated the mRNA expression of multiple members of this family (MT1F, MT1X, and $M T 2 A$, by a factor of $\geq 2$ ) (Table V). This effect was specific to ethanol, as it was not seen in response to treatment with $2.5 \mathrm{mM}$ acetaldehyde. The upregulation detected by DNA microarray analysis was also confirmed by RT-PCR, as for example MT1X (Fig. 7). However, this significant upregulation seemed to be short-lived, since after the 4-week exposure, it declined to only a marginal increase (not shown) suggesting the adaptation of MCF-7 to ethanol in terms of metallothionein expression.

Effects of long-term ethanol exposure on the expression of miRs controlling the expression of genes related to stem cells, malignancy, and estrogen effects. MicroRNAs (miRs) function by suppressing the activities of specific target mRNAs. Although it is possible for multiple miRs to affect a specific mRNA, sometimes an inverse relationship is observed between the expression level of a particular miR and the prevalence of the polypeptide coded by its target mRNA. Therefore, identifying the global miR transcriptional signature in response to ethanol exposure is important in clarifying the mechanism(s) of action of ethanol on breast cancer, particularly in evaluating its putative estrogen-like effects. We therefore carried out 4-week incubations of MCF-7 monolayers with and without 
Table IV. Long-term ethanol exposure, and RT-PCR.

A, Selected genes with relevance to breast cancer that are upregulated after long-term exposure to ethanol

\begin{tabular}{|c|c|c|c|}
\hline Gene & Also known as & Control & Eth/Control \\
\hline STEAP4 & Stamp2 & 134 & 8 \\
\hline SERPINA3 & $\alpha-1$ antitrypsin & 1,235 & 7.7 \\
\hline SAMD9 & Sterile $\alpha$ motif domain 9 & 46 & 5.2 \\
\hline GDF15 & $\begin{array}{l}\text { Growth differentiation } \\
\text { factor } 15\end{array}$ & 2,915 & 3.6 \\
\hline KRT15 & Keratin 15 & 58 & 3.3 \\
\hline ITGB6 & Integrin $\beta$ & 79 & 3.1 \\
\hline OAS1 & 1-5A synthetase & 91 & 3 \\
\hline FGB & Fibrinogen, $\beta$ chain & 43 & 5.1 \\
\hline TP53INP1 & $\begin{array}{l}\text { p53-dependent damage- } \\
\text { inducible nuclear protein }\end{array}$ & 312 & 2.5 \\
\hline ТР63 & Tumor protein p63 & 68 & 2 \\
\hline PGR & Progesterone receptor & 494 & 2 \\
\hline PLAT & $\begin{array}{l}\text { Tissue plasminogen } \\
\text { activator }\end{array}$ & 105 & 2 \\
\hline FN1 & Fibronectin 1 & 222 & 1.9 \\
\hline KRT81 & Keratin 81 & 349 & 1.8 \\
\hline ATP2b4 & $\begin{array}{l}\text { Plasma membrane } \\
\text { calcium-4 transporting } \\
\text { ATPase }\end{array}$ & 516 & 2.4 \\
\hline
\end{tabular}

B, Genes identified by DNA microarray analysis were verified by RT-PCR. ${ }^{a}$

\begin{tabular}{lcc}
\hline Gene ID & $\begin{array}{c}\text { DNA microarray } \\
\text { ratio (Eth/cont) }\end{array}$ & $\begin{array}{c}\text { PCR ratio } \\
\text { (Eth/cont) }\end{array}$ \\
\hline SAMD9 & 4.3 & 3.1 \\
IFI6 & 4.1 & 3.9 \\
CEACAM6 & 2.2 & 4 \\
STEAP4 & 2.1 & 4.3 \\
ATP2b4 & 1.7 & 2.8 \\
CEACAM5 & 1.6 & 7.1 \\
GDF15 & 1.3 & 1.9 \\
SERPINA1 & 1.1 & 1.8 \\
\hline
\end{tabular}

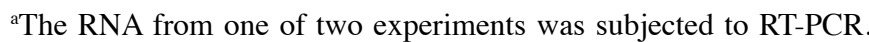
The DNA microarray upregulation ratios (Eth/cont) are compared with the PCR upregulation ratios (Eth/cont).

$25 \mathrm{mM}$ ethanol in duplicate experiments to investigate changes in miR prevalence.

Changes in the global expression signature of miRs induced by ethanol are presented in Table VI, showing that out of 1,904 miRs analyzed, $18 \mathrm{miRs}$ were consistently upregulated in two separate assays by a factor of $>2.0$ and another 24 were downregulated by at least an equivalent factor
Table V. MCF-7 cells treated for 1 week with $25 \mathrm{mM}$ ethanol were analyzed for gene expression using DNA microarray analysis. $^{\text {a }}$

Gene ID cont for ETh Eth/cont cont for Acet Acet/cont

\begin{tabular}{lrrrr}
\hline MT1A & 321 & 1.09 & 188 & 1.15 \\
MT1B & 206 & 1.31 & 66 & 0.99 \\
MT1F & 1,749 & 2.27 & 2,014 & 1.03 \\
MT1G & 748 & 1.71 & 4,768 & 0.78 \\
MT1H & 196 & 1.47 & 133 & 1.29 \\
MT1L & 940 & 1.76 & 501 & 1.00 \\
MT1X & 836 & 2.71 & 812 & 0.85 \\
MT2A & 5,225 & 1.95 & 7,099 & 0.81 \\
MT3 & 395 & 0.89 & 275 & 1.11 \\
MT4 & 155 & 1.08 & 90 & 1.19 \\
\hline
\end{tabular}

${ }^{a}$ The results for the metallothionein gene family are shown. Gene ID per NCBI Gene. Eth, values for cells treated with ethanol; Acet, values for cells treated with acetaldehyde.
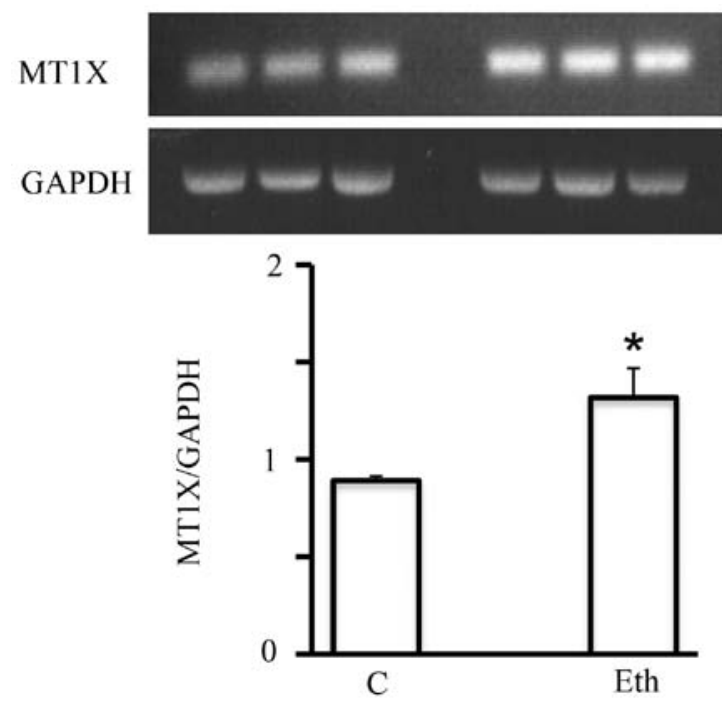

Figure 7. Short-term exposure to $25 \mathrm{mM}$ ethanol, but not to $2.5 \mathrm{mM}$ acetaldehyde increases the transcriptional expression of most metallothionein genes. Top, control and ethanol-treated samples analyzed for MT1X by RT-PCR Bottom, densitometric determination of ethanol-treated vs. control samples. ${ }^{*} \mathrm{p}<0.05$.

(to $\leq 0.5$ ). Of these, 4 miRs showed substantial upregulation (by $>3.0$ ) and 9 miRs were substantially downregulated (to $\leq 0.33$ ). Within the group of 4 upregulated genes, 3 are linked to cancer, namely miR-3170 which is downregulated in Merkel cell carcinoma (54), miR-335-5p which is linked to fibrosarcoma (55) and colorectal cancer but was negative in at least one study in MCF-7 (56), and miR-424-5p which is increased in breast cancer through an estrogen stimulated pathway (57) but is anti-invasive in another system (58). Within the group of 9 downregulated miRs, 5 are also related to cancer: miR-2861 is upregulated in thyroid carcinoma with lymph node metastases (59) but has been suggested as one element in a circulating miR screen for cervical cancer (see Discussion), miR-3185 for 
Table VI. Long-term exposure to $25 \mathrm{mM}$ ethanol and expression of miRs involved in cancer and stem cells. ${ }^{\mathrm{a}}$

\begin{tabular}{|c|c|c|c|c|c|}
\hline miRs upregulated & Cont & Eth/Cont & miRs downregulated & Cont & Eth/Cont \\
\hline hsa-miR-3170 & 28 & 3.87 & hsa-miR-4507 & 914 & 0.51 \\
\hline hsa-miR-335-5p & 80 & 3.58 & hsa-miR-4687-3p & 819 & 0.49 \\
\hline hsa-miR-424-5p & 2,046 & 3.18 & hsa-miR-320e & 394 & 0.49 \\
\hline hsa-miR-3607-3p & 411 & 3.01 & hsa-miR-4734 & 1,819 & 0.48 \\
\hline hsa-miR-20b-5p & 226 & 2.92 & hsa-miR-4516 & 6,902 & 0.48 \\
\hline hsa-miR-148a-3p & 548 & 2.70 & hsa-miR-4530 & 6,332 & 0.48 \\
\hline hsa-miR-494 & 2,012 & 2.69 & hsa-miR-638 & 11,664 & 0.46 \\
\hline hsa-miR-4284 & 4,767 & 2.53 & hsa-miR-4508 & 4,645 & 0.44 \\
\hline hsa-miR-23c & 85 & 2.38 & hsa-miR-3656 & 6,310 & 0.43 \\
\hline hsa-miR-126-3p & 168 & 2.31 & hsa-miR-3196 & 6,608 & 0.43 \\
\hline hsa-miR-30a-5p & 1,452 & 2.29 & hsa-miR-5001-5p & 8,936 & 0.42 \\
\hline hsa-miR-3607-5p & 3,251 & 2.28 & hsa-miR-4505 & 1,873 & 0.40 \\
\hline hsa-miR-141-3p & 1,297 & 2.18 & hsa-miR-663a & 9,642 & 0.39 \\
\hline hsa-miR-454-3p & 255 & 2.16 & hsa-miR-762 & 1,375 & 0.37 \\
\hline hsa-miR-29a-3p & 2,275 & 2.16 & hsa-miR-3940-5p & 3,288 & 0.34 \\
\hline hsa-miR-3676-5p & 153 & 2.06 & hsa-miR-1469 & 267 & 0.33 \\
\hline hsa-miR-429 & 369 & 2.04 & hsa-miR-4466 & 5,285 & 0.33 \\
\hline hsa-miR-106b-5p & 1,869 & 2.02 & hsa-miR-4492 & 1,515 & 0.32 \\
\hline \multirow[t]{6}{*}{ hsa-miR-106a-5p } & 795 & 1.96 & hsa-miR-4707-5p & 5,583 & 0.30 \\
\hline & & & hsa-miR-1915-3p & 3,695 & 0.29 \\
\hline & & & hsa-miR-3185 & 555 & 0.26 \\
\hline & & & hsa-miR-4800-3p & 1,374 & 0.24 \\
\hline & & & hsa-miR-2861 & 1,437 & 0.22 \\
\hline & & & hsa-miR-654-5p & 5,651 & 0.21 \\
\hline
\end{tabular}

${ }^{a}$ Upregulated miRs are shown on the left, and downregulated miRs are shown on the right.

chordoma (60), miR-1915 whose downregulation would predict an antiapoptotic effect (and therefore potential oncogenicity) mediated through Bcl-2 (61), miR-4492 potentially linked to breast cancer (62), and miR-1469 downregulation linked to lymphatic metastasis in gastric cancer (63) but a stimulatory factor for apoptosis in lung cancer cells (64).

In Table VII, we group other miRs affected by long-term ethanol exposure of MCF-7, focusing on whether these miRs may be related to two additional important issues that may underlie the observed intensification of MCF-7 malignant features: a) the finding of upregulation of Oct4 and Ceacam6 protein expression; and b) the putative mediation of alcohol effects by estrogen-like mechanisms. In Table VII, miRs whose expression was affected in general by a factor of $>2$ are listed based on a relationship with one or more of these issues. In terms of the Oct4 regulation, Let-7 has been reported to repress Oct4 protein expression (65) and after ethanol treatment it is substantially downregulated from high levels seen in the non-exposed control. Considering the observed lack of OCT4 gene transcriptional upregulation in the presence of ethanol, concomitant with the observed stimulation of Oct4 protein, this miR change is very pertinent in this context. In turn, with respect to possible miRs targeting Ceacam6, only one likely miR was downregulated (149-3P) (66) which would be consistent with Ceacam6 upregulation, although three
Table VII. Long-term exposure to $25 \mathrm{mM}$ ethanol affects miRs involved in oncogenesis and in estrogen effects.

\begin{tabular}{lrl}
\hline miR & \multicolumn{1}{c}{$\mathrm{C}$} & Eth/C \\
\hline Let-7a-5p & 6,095 & 0.6 \\
miR-15A-5p & 310 & 2.57 \\
miR-16-5p & 4,286 & 2.01 \\
miR-195-5p & 910 & 2.32 \\
miR-149-3p & 2,067 & 0.15 \\
Let-7b & 2,737 & 0.66 \\
Let-7c & 4,158 & 0.64 \\
miR-424-5p & 2,046 & 3.18 \\
miR-494 & 2,012 & 2.69 \\
miR-27a & 3,888 & 2.09 \\
miR-27 & 2,254 & 2.43 \\
miR-429a & 369 & 2.04 \\
miR-16 & 4,286 & 2.01 \\
miR-203 & 2,482 & 2.15 \\
miR-342 & 3,339 & 1.83 \\
miR-200a & 854 & 2.44 \\
\end{tabular}

amiRs also listed in Table VI. 


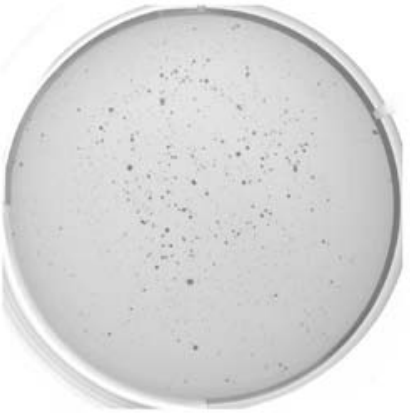

Control

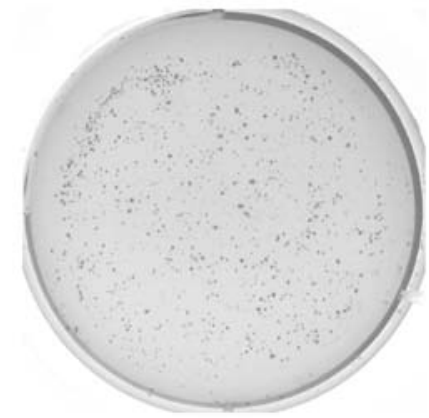

Ethanol $25 \mathrm{mM}$

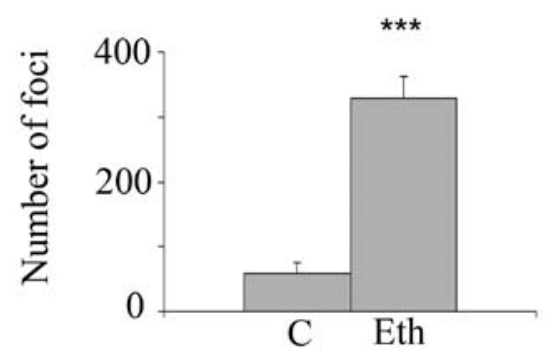

Figure 8. Long-term exposure to $25 \mathrm{mM}$ ethanol stimulates MCF-7 anchorageindependence as detected by the soft agar procedure. Top, representative images of the crystal violet staining of typical plates of soft agar growth for $25 \mathrm{mM}$ ethanol. Bottom, foci number for each type of incubation as mean of 4 experiments, each experiment using triplicate wells. ${ }^{* * * *} \mathrm{p}<0.001$.

(15a-5P, 16-5P and 195-5P) were upregulated, but their relationship with Ceacam6 is less clear.

In terms of a possible relationship with estrogen pathways, Table VII shows several miRs affected by long-term ethanol exposure that are known to modulate or be modulated by estrogen-mediated processes or estrogen responsiveness, specifically 6 that are upregulated (16, 27a, 27b, 200a, 203, and 342) and 3 downregulated (let7b, 7c and 7d) (see Discussion).

Long-term exposure of MCF-7 cells to ethanol, but not to acetaldehyde, stimulates anchorage-independence. In order to determine whether long-term exposure to ethanol or acetaldehyde stimulates anchorage-independence, an in vitro marker of oncogenic transformation, incubations with $2.5-25 \mathrm{mM}$ ethanol or $2.5 \mathrm{mM}$ acetaldehyde were carried out for 4 weeks followed by 3-4 weeks growth in the clonogenic soft agar assay. Fig. 8 shows that $25 \mathrm{mM}$ ethanol treatment substantially and significantly increases the number of anchorage-independent foci by 5.6-fold (4 separate experiments, each in triplicate), which agrees with the protein expression and transcriptional signature changes related to stem cell and oncogenic features. In addition, after exposure to a lower ethanol concentration $(10 \mathrm{mM})$, there was a substantial and significant increase in anchorage-independence of 3.85 -fold $(\mathrm{p}=0.014)$ for triplicate ethanol wells and duplicate control wells. However, exposure to further ethanol dilutions, 2.5 or $5 \mathrm{mM}$, had no significant effect. As in the case of 1-week incubation, long-term treatment with $2.5 \mathrm{mM}$ acetaldehyde did not stimulate foci formation (data not shown).

In contrast to the clonogenic assay, incubation of 25,000 cells with $25 \mathrm{mM}$ ethanol for 4 weeks was not associated with the stimulation of invasiveness in the Matrigel assay (data not shown). It should be noted that the MCF-7 cell line is not invasive per se. There were only trace numbers of positive cells (mean of 4 samples each: control mean 11.25 \pm 2.4 SE; ethanol mean 14.5 $\pm 2.9 \mathrm{SE}$ ) and there was no statistical significance ( $p=0.68$, two-tailed t-test). Moreover, there was no induction of tamoxifen resistance after incubation for 4 weeks with $25 \mathrm{mM}$ ethanol as analyzed by cellular metabolism in the presence of increasing levels of the drug (data not shown).

\section{Discussion}

To our knowledge this is the first report on the in vitro long-term effects of ethanol on breast cancer cells at doses comparable to peak exposures in humans, and describing multiple targets of potential cancer-related impact. These effects are not exerted by acetaldehyde, and are largely inconsistent with respect to estrogen-mediated effects. Therefore, our results do not support the prevalent hypothesis that ethanol action in cancer-related processes functions mainly through estrogenic or acetaldehyde mediation, although future, more mechanistic work is needed to test this assumption, particularly in relation to the potential estrogen mediation.

In a previous study (1), we investigated the effects of ethanol exposure on a non-malignant, spontaneously immortalized breast epithelial cell line, MCF-12A. We found that relatively low doses of ethanol stimulated markers for epithelial mesenchymal transition (EMT), as shown by changes in mRNAs and miRs. We also found some upregulation in the stem-related proteins Oct4 and Nanog, as well as in the oncogenic marker Ceacam6. The results with respect to these phenomena are remarkably similar in this study of MCF-7, although the levels of ethanol necessary to achieve the observed changes differed. Ethanol incubation induced a gene expression signature in MCF-12A that includes short-term upregulation of one gene family in particular, the metallothioneins, similar to that observed in MCF-7.

In this study, we have shown that: i) an exposure as short as 1 week to $25 \mathrm{mM}$ ethanol stimulates the transcriptional expression of the metallothionein gene family in MCF-7, showing that even in an established cancer cell line, the effect of ethanol on MT expression occurs; this short-term ethanol treatment does not, however, induce any substantial change in the global transcriptional signature related to the expression of stem cell or oncogenic markers in monolayers or mammospheres; ii) in contrast, longer (4-week) exposure of MCF-7 monolayers to 5-25 $\mathrm{mM}$ ethanol leads to upregulation of the key stem cell proteins Oct4 and Nanog, and of a key oncogenic protein, Ceacam6, demonstrating that phenomena previously observed in MCF-12A are maintained in the established cancer line MCF-7; iii) in MCF-7 mammospheres incubated long-term with ethanol, only Ceacam6 remains upregulated, and there is no effect on mammosphere number or size; iv) changes in Ceacam6 protein expression are reflected in RNA expression, but the same phenomenon is not observed for Oct 4 or Nanog protein expression, suggesting their regulation at the translational level.

In addition, of even more significant pathological relevance, we showed that: v) in MCF-7 monolayers, long-term effects induced by $25 \mathrm{mM}$ ethanol include substantial changes in the global transcriptional signature, including upregulation 
of immune-related genes, HLAs, and in particular, a series of genes involved in breast cancer; vi) this long-term oncogenic intensification of the transcriptional signature by ethanol is associated with the stimulation of anchorage-independence, a marker of increased malignancy; vii) this putative transformation exerted by ethanol is not associated with induction of tamoxifen resistance, potentially related to estrogen effects, or of invasiveness; viii) ethanol effects on miR expression are largely inconsistent with the hypothesis that ethanol effects are entirely or even largely mediated through estrogenic pathways; rather, there are conflicting effects such that some miR expression follows this pattern and other miR expression goes in the direction that is opposite to what would be expected under the estrogenic hypothesis; ix) most of the alterations we observed following ethanol treatment do not appear to be mediated by acetaldehyde.

We do not have a conclusive explanation for the temporal pattern showed by oncogenic effects due to long-term exposure to ethanol, but speculate as to two possible mechanisms: i) ethanol effects on gene expression may result from a cascade of regulatory events that requires multiple cell divisions to complete; or ii) longer term exposure to ethanol not only affects gene expression, it selects for a subset of cells within the original population; thus the partially toxic effects of ethanol might be reflected in gene expression changes that accumulate over the course of several cell division cycles.

Before analyzing the mechanistic significance of these alterations, it is important to stress the limitations of this study, in that it is essentially an in vitro proof-of-concept approach, based on the cell line, MCF-7, similar to what we cautiously stated regarding our previous study on the normal MCF-12A cell line (1). The malignant MCF-7 cell line was derived from a metastatic site of a breast cancer tumor and is widely used as a model for breast cancer studies. Our results need to be confirmed and extended in vitro using lower concentrations of ethanol and by examination of the interconnections between observed gene expression alterations. It should be noted that in our previous study on MCF-12A cells, considerably lower levels of ethanol led to substantial effects on protein, mRNA, and $\mathrm{miR}$ prevalence, and that their long-term exposure to high $25 \mathrm{mM}$ levels arrested their growth and ultimately was toxic to the cells. In a simplistic comparison, this would mean that the stimulation of malignant features (MCF-7) requires a higher concentration of ethanol than their induction (MCF-12A).

To better extrapolate these MCF-7 results to the human, in vivo confirmation is required in experimental animals. Although the in vitro exposure to ethanol concentrations of 5-25 mM, roughly equivalent in women to peak human serum concentrations after 0.6-3 glasses of wine taken during a 2-h period, was maintained continuously, its duration of only 4 weeks is certainly much shorter than the cumulative years of exposure that a human drinker experiences in a lifetime. There is no easy calculation of the equivalence between cell culture incubations and breast tumor tissue exposures, particularly because MCF-7 cultures may not reflect the complex stromal/ epithelial interactions involved in breast cancer progression. Despite the above limitations, this study calls attention to the existence of molecular alterations in breast tumor cells induced by ethanol that may open up directions to further investigations on breast cancer in women.
It is of interest that the metallothioneins are members of a family of genes known to be induced by ethanol (52) and comprising members such as MT-I and MT-II that are antiapoptotic, proliferative, angiogenic, and oncogenic (53). The expression of MT-I and MT-II is increased in breast cancer and other tumors, correlating with higher tumor grade/stage, increased recurrence and poor survival in the highly malignant invasive ductal breast carcinomas, and predicting poor prognosis in estrogen receptor-negative patients. Although the stimulation of metallothionein gene expression is indicative of gene expression effects beginning as soon as a few days after the administration of alcohol, the stimulation of metallothionein gene expression did not persist in our model system, so the long-term effect of these gene changes with respect to oncogenesis remains uncertain. As noted above, the temporal course of action in MT genes are similar for both the malignant MCF-7 cells and the non-malignant MCF-12A cells.

A consistent pattern of changes induced by long-term ethanol, but not acetaldehyde, is the correlation between the upregulation of the key stem cell proteins Oct4a and Nanog (67) and an important cancer marker, Ceacam6 (50), in addition to the induction of anchorage-independence evidenced by soft agar growth. OCT4 is well known as a key gene responsible for the stemness network, and the main factor in the generation of induced pluripotent stem cells (iPS). More recently, OCT4 has emerged as a key oncogenic factor related to the role of cancer stem cells (68). For instance, expression of the Oct 4 protein is higher in cancerous tissues than in adjacent-tumor tissues, is related to histological type, lymph node status and molecular type of breast cancer, and together with Her-2, is an independent prognostic factor for breast cancer $(69,70)$, although it seems to occur later than SOX2 activation $(71,72)$. In MCF-7 cells, estrogen stimulates and metformin reduces the size and number of mammospheres and their expression of Oct4 (73).

However, our current results must be viewed as speculative as to whether they connect the observed upregulation of Oct 4 to increased malignancy, since in another study, silencing OCT4 promoted invasion and metastasis in MCF-7 cells by inducing EMT (74). The very low expression of Oct 4 detected by us in MCF-7 monolayers in the absence of ethanol is consistent with observations from other studies $(75,76)$, and the potentially oncogenic upregulation by ethanol has not been previously reported. As to $N A N O G$, there is extensive evidence linking it to breast cancer directly or through its activation by $S O X 2$, alone or in conjunction with KLF4 (77), and it is known that ethanol induces Nanog in embryonic stem cells and hepatic carcinogenesis (78).

The upregulation of CEACAM6 after long-term $25 \mathrm{mM}$ ethanol exposure is consistent with a more aggressive phenotype of MCF-7 cells in vitro (75). Ceacam6, a membraneassociated cell adhesion protein, is overexpressed in breast cancer and a variety of other tumors, and is considered to be a marker of invasiveness and metastasis, a predictor of breast cancer recurrence, and specifically of invasive breast cancer in women with atypical ductal hyperplastic tissues (79-82). There are no previous reports of ethanol effects on CEACAM6, or on a link between $C E A C A M 6$ and $O C T 4$ expression in any other context save our previous study on non-malignant cells (1), and the correlation of this upregulation to the intensification of anchorage-independence has not been reported previ- 
ously except in our previous report (1), thus showing that this phenomenon is observed in both malignant and non-malignant cells derived from breast epithelium. Similarly, the stimulation of MCF-7 growth in soft agar due to exposure to ethanol at a dose as low as $10 \mathrm{mM}$ has not been described before except in the previous report (1), since previous studies (20-26) used high concentrations of ethanol (90-110 mM), short periods of exposure (48 h), and in some cases, breast cancer cell lines other than MCF-7.

The stimulation by long-term ethanol of the expression of Ceacam6 protein is in agreement with the observed transcriptional upregulation of CEACAM6 and CEACAM5 and with other $C E A C A M s$. The observed stimulation is also paralleled by the increase in mRNA levels for a series of oncogenesisrelated genes, STEAP4 (83,84), SERPINA3 (84), SAMD9 (85), GDF-15 (86), KRT15 (87), TP53INPI (88), IF16 or G1P3 (89), and $H L A-G(90)$ as well as other members of the $H L A$ family, all of which have in common their breast cancer-related expression and the fact that none has been reported as being upregulated by ethanol. Some of these genes (SERPINA3, $G D F 15, I F I 6)$ are also modulated by estrogen, but only one, GDF 15, was previously studied in MCF-7. Surprisingly, no reports are available on the relationship of any of these genes with either OCT4 or CEACAM6.

No evidence of preferential stimulation of stem cell accumulation following ethanol treatment in either MCF-7 monolayers or mammospheres could be found by gene expression analysis, as judged by the lack of meaningful changes in the transcriptional expression of a series of stem cell genes, including OCT4 and Nanog. This finding is in agreement with the similarity between the transcriptional signatures of mammospheres and monolayers in the absence of ethanol. This is puzzling within the framework of the significant upregulation of Oct4 and Nanog protein expression induced by long-term ethanol. OCT4 and NANOG are key stem cell genes in a network of other genes involved in stemness, but which are expressed transcriptionally in this study at only a low level, and not changed by ethanol treatment. A possible explanation could involve translational regulation mediated by miRs (see below). It is also conceivable that OCT4 and $N A N O G$ act as oncogenic factors per se, unrelated to stem cell activation, or speculatively may be due to the failure of stem cells to form mammospheres, but no supporting data exist in these in respect of other than OCT4 overexpression in breast cancer and other tumors.

The seeming contradiction between Oct4 protein upregulation in the absence of detectable Oct 4 mRNA increase suggests a model in which untreated cells exist in a state of translational repression of Oct 4 due to some miR or combination of miRs. According to this hypothesis, some miRs such as Let-7A-5P (which is reduced in prevalence by ethanol exposure) allows the induction, by its partial absence, of overexpression of the Oct4 protein. Other Let-7 family members are also substantially expressed in control cells and reduced by ethanol. Let-7A has been shown to function as a tumor suppressor in head and neck cancers and in their associated tumor initiating cells, where it is significantly decreased when OCT4 expression was increased (65). However, it is not clear that this is only translational repression and NANOG is also affected, so it is possible that Let-7 might not be responsible by itself for the selective upregulation of Oct 4 protein, and it works in conjunction with the opposite effects of Lin 28b. Another miR, miR-145 functions as a protective miRNA in tumor tissues of lung adenocarcinoma patients and binds to the OCT4 3'-untranslated region (UTR) thus blocking protein expression correlated with anti-oncogenic action (91-93), but we did not detect significant changes in this miR. The same uncertainty applies to the putative interaction between the downregulation of miR-149-3p by long-term ethanol, that would be consistent with the observed upregulation of CEACAM6 mRNA and protein, and the counterintuitive upregulation of miR-15A-5p, $16-5 p$, and 195-5p that could potentially oppose this effect. However, these are inferences based purely on sequence analogies in the miRBase 18.0 (94) and without mechanistic proof as yet. Therefore, the roles of the changes in miR levels in relation to the upregulation of Oct4, Nanog, and Ceacam6 induced by long-term ethanol in MCF-7 require further study.

The molecular signature of miRs related to estrogen responsiveness is key to understanding whether ethanol may act via estrogenic pathways on luminal-like breast tumor cells, such as the MCF-7, to induce or stimulate their proliferation, survival, and functional status through the estrogen receptor $\alpha$. Alcohol is assumed to increase sex hormone levels in both premenopausal and postmenopausal women (6) by: a) increased aromatase activity; b) decreased hepatic catabolism of androgens; c) modulation of adrenal steroid production; and d) by increasing the expression or transcriptional activity of $E R \alpha$. Alcohol may also preferentially enhance cellular proliferation and $E R \alpha$ content in ER-positive cell lines (15-18). Therefore, it might be expected that long-term ethanol effects on miRs in MCF-7 would mimic those exerted by estrogen or those related to estrogen responsiveness, but no reports are available on ethanol effects on any miR profile except in our recently published study on non-malignant cells (1).

One of the miRs we found upregulated in MCF-7, miR-424, was also shown to be induced by $17-\beta$-estradiol in at least two $(95,96)$ of the multiple studies conducted in MCF-7. In some cases, ethanol induced upregulation is also seen after estrogen treatment, such as in miR-27a and b (96). The fact that ethanol affected any particular miR in this study did not necessarily coincide with affects on other miRs that would be expected to change comcomitantly if ethanol action were limited to one specific pathway such as the estrogenic pathway: thus upregulated miRs such as miR-107, miR-424, miR-570, miR-618, and miR-760 (95), miR-21 (28), miR-34b (97), miR-98 (98), miR-19A and miR-24 (96), miR-26a and b (99), miR-17 $(100,101)$, miR-7 (102), or miR-190a (103); or downregulated miRs such as miR-16, miR-143, or miR-203 (104). Interestingly, the latter is the opposite of what we observed with ethanol.

Although there are 4 miRs where both ethanol and estradiol induce the same changes in MCF-7, there are at least $18 \mathrm{miRs}$ known to be affected by estrogen that can target a significant number of transcripts belonging to one or more estrogenresponsive gene clusters, but were not modified by ethanol in this study. In turn, 5 of our ethanol responsive changes have not been reported in global miR transcription studies conducted with estrogen or estrogenic compounds in MCF-7. The scope of this report does not cover the elucidation of how these miRs may act in terms of oncogenic or tumor suppressor effects. However, it is worth mentioning that out of the miRs whose 
levels have previously been shown to be regulated by estrogen and/or to modulate its receptor, and that were found in our work to be changed by ethanol, only the miR-27a and miR-27b levels were modulated as predicted by their role in estrogen responsiveness. It is also known that miR-27a is oncogenic in the triple-negative MDA-MB-231 breast cancer cell line, and indirectly regulates E2-responsiveness in MCF-7 cells through suppression of $Z B T B 10$, thereby enhancing expression of $\mathrm{ER} \alpha(47,48)$. In turn, miR-27a is upregulated in endometrial adenocarcinoma and precancerous lesions in response to estrogen overexposure. However, let-7 behaves similarly in the hyperplastic endometrium $(98,105)$ and most members of this family (b, c and d) are considered to be pro-estrogenic. In this study they were uniformly reduced.

The lack of consistency between the ethanol modulation of miR levels and their relationship with estrogen responsiveness is confirmed by our results with miR-16 (106), miR-200a (47), miR-203 (47), and miR-342 (107), which, as in the case of let-7a, b, and c, are opposite to what could be expected from an estrogen-like effect. However, since miRs exert pleiotropic effects, a mere association with estrogen-mediated pathways is not sufficient to conclude that those may not be involved in the observed ethanol effects on MCF-7 cultures. It should be emphasized that many of these miRs also affect other processes different from estrogenic effects, as described in a large and growing literature. For example, the Let-7 family is highly conserved and is involved in development, stem cell modulation, oncogenesis, and the cardiovascular system among other things (108), while the miR 15/107 group containing miR-15 and miR-16 affects BRCA1 expression (109), and miR-195 and miR-29 have been linked to aortic aneurism (110).

Regarding the ethanol/estradiol comparison of miR signatures, we note the limitation that our study was long-term, whereas the previous estrogen studies varied in duration, but we propose that estradiol effects do not seem to define more than a small proportion of the changes in the global miR transcriptional signature of MCF-7 induced by ethanol. The ethanol induced changes are specific and at least partially different from estrogen-induced changes. Thus this study does not provide strong support for the hypothesis that estrogen mediates ethanol effects. Further studies are needed, vis-à-vis ethanol and estrogen, and with anti-estrogenic agents, to clarify the estrogenic mediation of long-term ethanol effects on $\mathrm{MCF}-7$.

A recent review lists a large number of miRs that are involved in cancer-related processes ranging from tumor suppression to various oncogenic features (111). We note that several miRs listed in that review show ethanol effects in this study, including miRs 15a, 16, the Let-7 family, 27a, 148a, and 149 . We should also point out that ethanol does not necessarily promote oncogenesis in every case, for example tumor suppressors miR-15a and miR-16 are upregulated in response to ethanol treatment. However, the same two miRs were found to be upregulated in a biomarker test distinguishing sepsis from systemic inflammatory response (112). In this study, we found that exposure of MCF-7 cells to ethanol results in detectable changes in the expression of miRs such as miR-29a associated with inflammation (113). Interestingly, miR-15a upregulation is found in the serum of humans exposed to particulate air pollution (114). In another study, it was found that miR-29a is potentially able to stimulate the conditions for metastasis by binding to Toll-like receptors (115).

Some miRs that have been proposed for inclusion as circulating cancer markers in the clinical setting show changes in expression levels in response to ethanol. This suggests that such markers should be considered carefully with regard to the ethanol intake status of the patient. For example, miR-424 has been proposed for inclusion in a group of circulating biomarkers for breast cancer (116), and miR-2861 is upregulated in thyroid carcinoma with lymph node metastases (59) but has been suggested as one element in a circulating miR screen for cervical cancer, where it has been shown to be decreased (117).

In conclusion, our overall results suggest that prolonged exposure to ethanol may lead to the intensification of a series of novel oncogenic features in breast cancer by mechanisms that are not directly related to acetaldehyde and which do not strongly indicate estrogen mediation. These features require further clarification, with the caveat that the in vitro incubations using a breast cancer cell line are not directly extrapolatable to alcohol consumption in women. Our results may suggest some kind of stem cell involvement, but one which so far shows contradictory transcriptional and translational aspects. However, in conjunction with our findings on the induction of oncogenic features in a normal breast epithelial cell line (1), the current data may constitute the first comparison of global transcriptional signatures elicited by long-term ethanol exposure on normal and cancer breast cells, and the defining of potentially oncogenic features exacerbated by alcohol. Moreover, miRs in circulation are now being proposed as a diagnostic tool for both carcinomas and metatatic carcinomas (118). Therefore, the observation that ingested ethanol affects miR levels may have clinical significance, particularly with respect to miR values measured in heavy drinkers.

\section{References}

1. Gelfand R, Vernet D, Bruhn K, Vadgama J and GonzalezCadavid NF: Long-term exposure of MCF-12A normal human breast epithelial cells to ethanol induces epithelial mesenchymal transition and oncogenic features. Int J Oncol 48: 2399-2414, 2016.

2. Seitz HK, Pelucchi C, Bagnardi V and La Vecchia C: Epidemiology and pathophysiology of alcohol and breast cancer: Update 2012. Alcohol Alcohol 47: 204-212, 2012.

3. Coronado GD, Beasley J and Livaudais J: Alcohol consumption and the risk of breast cancer. Salud Publica Mex 53: 440-447, 2011.

4. Pelucchi C, Tramacere I, Boffetta P, Negri E and La Vecchia C: Alcohol consumption and cancer risk. Nutr Cancer 63: 983-990, 2011.

5. Chen WY, Rosner B, Hankinson SE, Colditz GA and Willett WC: Moderate alcohol consumption during adult life, drinking patterns, and breast cancer risk. JAMA 306: 1884-1890, 2011.

6. Narod SA: Alcohol and risk of breast cancer. JAMA 306: 1920-1921, 2011.

7. Saxena T,Lee E, Henderson KD, Clarke CA, West D, Marshall SF Deapen D, Bernstein L and Ursin G: Menopausal hormone therapy and subsequent risk of specific invasive breast cancer subtypes in the California Teachers Study. Cancer Epidemiol Biomarkers Prev 19: 2366-2378, 2010.

8. Allemani C, Berrino F, Krogh V, Sieri S, Pupa SM, Tagliabue E, Tagliabue G and Sant M: Do pre-diagnostic drinking habits influence breast cancer survival? Tumori 97: 142-148, 2011.

9. Jelski W, Chrostek L, Szmitkowski M and Markiewicz W: The activity of class I, II, III and IV alcohol dehydrogenase isoenzymes and aldehyde dehydrogenase in breast cancer. Clin Exp Med 6: 89-93, 2006.

10. Seitz HK and Stickel F: Molecular mechanisms of alcoholmediated carcinogenesis. Nat Rev Cancer 7: 599-612, 2007. 
11. Hirano T: Alcohol consumption and oxidative DNA damage. Int J Environ Res Public Health 8: 2895-2906, 2011.

12. Balbo S, Meng L, Bliss RL, Jensen JA, Hatsukami DK and Hecht SS: Time course of DNA adduct formation in peripheral blood granulocytes and lymphocytes after drinking alcohol. Mutagenesis 27: 485-490, 2012.

13. Seitz HK and Stickel F: Acetaldehyde as an underestimated risk factor for cancer development: Role of genetics in ethanol metabolism. Genes Nutr 5: 121-128, 2010

14. Wong AW, Dunlap SM, Holcomb VB and Nunez NP: Alcohol promotes mammary tumor development via the estrogen pathway in estrogen receptor alpha-negative HER2/neu mice. Alcohol Clin Exp Res 36: 577-587, 2012.

15. Singletary KW, Frey RS and Yan W: Effect of ethanol on proliferation and estrogen receptor-alpha expression in human breast cancer cells. Cancer Lett 165: 131-137, 2001.

16. Etique N, Chardard D, Chesnel A, Merlin JL, Flament S and Grillier-Vuissoz I: Ethanol stimulates proliferation, ERalpha and aromatase expression in MCF-7 human breast cancer cells. Int J Mol Med 13: 149-155, 2004.

17. Etique N, Flament S, Lecomte J and Grillier-Vuissoz I: Ethanolinduced ligand-independent activation of ERalpha mediated by cyclic AMP/PKA signaling pathway: An in vitro study on MCF-7 breast cancer cells. Int J Oncol 31: 1509-1518, 2007.

18. Etique N, Grillier-Vuissoz I, Lecomte J and Flament S: Crosstalk between adenosine receptor (A2A isoform) and ERalpha mediates ethanol action in MCF-7 breast cancer cells. Oncol Rep 21: 977-981, 2009.

19. Przylipiak A, Rabe T, Hafner J, Przylipiak M and Runnebaum R: Influence of ethanol on in vitro growth of human mammary carcinoma cell line MCF-7. Arch Gynecol Obstet 258: 137-140, 1996.

20. Meng Q, Gao B, Goldberg ID, Rosen EM and Fan S: Stimulation of cell invasion and migration by alcohol in breast cancer cells Biochem Biophys Res Commun 273: 448-453, 2000.

21. Luo J and Miller MW: Ethanol enhances erbB-mediated migration of human breast cancer cells in culture. Breast Cancer Res Treat 63: 61-69, 2000.

22. Izevbigie EB, Ekunwe SI, Jordan J and Howard CB: Ethanol modulates the growth of human breast cancer cells in vitro. Exp Biol Med (Maywood) 227: 260-265, 2002.

23. Etique N, Chardard D, Chesnel A, Flament S and GrillierVuissoz I: Analysis of the effects of different alcohols on MCF-7 human breast cancer cells. Ann NY Acad Sci 1030: 78-85, 2004

24. Etique N, Grillier-Vuissoz I and Flament S: Ethanol stimulates the secretion of matrix metalloproteinases 2 and 9 in MCF-7 human breast cancer cells. Oncol Rep 15: 603-608, 2006.

25. Verma M and Davidson EA: MUC1 upregulation by ethanol Cancer Biochem Biophys 17: 1-11, 1999.

26. Ma C, Lin H, Leonard SS, Shi X, Ye J and Luo J: Overexpression of ErbB2 enhances ethanol-stimulated intracellular signaling and invasion of human mammary epithelial and breast cancer cells in vitro. Oncogene 22: 5281-5290, 2003.

27. Aye MM, Ma C, Lin H, Bower KA, Wiggins RC and Luo J: Ethanolinduced in vitro invasion of breast cancer cells: The contribution of MMP-2 by fibroblasts. Int J Cancer 112: 738-746, 2004.

28. Ke Z, Lin H, Fan Z, Cai TQ, Kaplan RA, Ma C, Bower KA Shi $\mathrm{X}$ and Luo J: MMP-2 mediates ethanol-induced invasion of mammary epithelial cells over-expressing ErbB2. Int J Cancer 119: 8-16,2006.

29. Cordes T, Diesing D, Becker S, Diedrich K, Reichrath J and Friedrich M: Modulation of MAPK ERK1 and ERK2 in VDR-positive and -negative breast cancer cell lines. Anticancer Res 26A: 2749-2753, 2006.

30. Xu M, Bower KA, Wang S, Frank JA, Chen G, Ding M, Wang S, Shi X, Ke Z and Luo J: Cyanidin-3-glucoside inhibits ethanolinduced invasion of breast cancer cells overexpressing ErbB2. Mol Cancer 9: 285, 2010

31. Raouf A, Sun Y, Chatterjee S and Basak P: The biology of human breast epithelial progenitors. Semin Cell Dev Biol 23: 606-612, 2012.

32. Bruno RD and Smith GH: Role of epithelial stem/progenitor cells in mammary cancer. Gene Expr 15: 133-140, 2011.

33. Korkaya H, Liu S and Wicha MS: Breast cancer stem cells, cytokine networks, and the tumor microenvironment. J Clin Invest 121: 3804-3809, 2011

34. Feifei N, Mingzhi Z, Yanyun Z, Huanle Z, Fang R, Mingzhu H, Mingzhi C, Yafei S and Fengchun Z: MicroRNA expression analysis of mammospheres cultured from human breast cancers. J Cancer Res Clin Oncol 138: 1937-1944, 2012.
35. Xie G, Zhan J, Tian Y, Liu Y, Chen Z, Ren C, Sun Q, Lian J, Chen L, Ruan J, et al: Mammosphere cells from high-passage MCF7 cell line show variable loss of tumorigenicity and radioresistance. Cancer Lett 316: 53-61, 2012.

36. Nash R, Krishnamoorthy M, Jenkins A and Csete M: Human embryonic stem cell model of ethanol-mediated early developmental toxicity. Exp Neurol 234: 127-135, 2012.

37. Worley SL, Vaughn BJ, Terry AI, Gardiner CS and DeKrey GK Time- and dose-dependent effects of ethanol on mouse embryonic stem cells. Reprod Toxicol 57: 157-164, 2015.

38. Cortez MA, Welsh JW and Calin GA: Circulating microRNAs as noninvasive biomarkers in breast cancer. Recent Results Cancer Res 195: 151-161, 2012.

39. Krell J, Frampton AE, Jacob J, Castellano L and Stebbing J: miRNAs in breast cancer: Ready for real time? Pharmacogenomics 13: 709-719, 2012

40. Shore AN, Herschkowitz JI and Rosen JM: Noncoding RNAs involved in mammary gland development and tumorigenesis: There's a long way to go. J Mammary Gland Biol Neoplasia 17: 43-58, 2012

41. Valastyan S: Roles of microRNAs and other non-coding RNAs in breast cancer metastasis. J Mammary Gland Biol Neoplasia 17: 23-32, 2012.

42. Guttilla IK, Adams BD and White BA: ER $\alpha$, microRNAs, and the epithelial-mesenchymal transition in breast cancer. Trends Endocrinol Metab 23: 73-82, 2012.

43. Jain P and Alahari SK: Breast cancer stem cells: A new challenge for breast cancer treatment. Front Biosci (Landmark Ed) 16: 1824-1832, 2011

44. Miranda RC, Pietrzykowski AZ, Tang Y, Sathyan P, Mayfield D, Keshavarzian A, Sampson W and Hereld D: MicroRNAs: Master regulators of ethanol abuse and toxicity? Alcohol Clin Exp Res 34: 575-587, 2010.

45. Meng F, Glaser SS, Francis H, Yang F, Han Y, Stokes A, Staloch D, McCarra J, Liu J, Venter J, et al: Epigenetic regulation of miR-34a expression in alcoholic liver injury. Am J Pathol 181: 804-817, 2012

46. Klinge CM: miRNAs and estrogen action. Trends Endocrinol Metab 23: 223-233, 2012

47. Guttilla IK, Phoenix KN, Hong X, Tirnauer JS, Claffey KP and White BA: Prolonged mammosphere culture of MCF-7 cells induces an EMT and repression of the estrogen receptor by microRNAs. Breast Cancer Res Treat 132: 75-85, 2012.

48. Li X, Mertens-Talcott SU, Zhang S, Kim K, Ball J and Safe S: MicroRNA-27a indirectly regulates estrogen receptor $\{$ alpha\} expression and hormone responsiveness in MCF-7 breast cancer cells. Endocrinology 151: 2462-2473, 2010.

49. Reed TE, Kalant H, Gibbins RJ, Kapur BM and Rankin JG: Alcohol and acetaldehyde metabolism in Caucasians, Chinese and Amerinds. Can Med Assoc J 115: 851-855, 1976.

50. Tsang JY, Kwok YK, Chan KW, Ni YB, Chow WN, Lau KF, Shao MM, Chan SK, Tan PH and Tse GM: Expression and clinical significance of carcinoembryonic antigen-related cell adhesion molecule 6 in breast cancers. Breast Cancer Res Treat 142: 311-322, 2013

51. Pece S, Tosoni D, Confalonieri S, Mazzarol G, Vecchi M, Ronzoni S, Bernard L, Viale G, Pelicci PG and Di Fiore PP: Biological and molecular heterogeneity of breast cancers correlates with their cancer stem cell content. Cell 140: 62-73, 2010.

52. Ono S, Ishizaki Y, Tokuda E, Tabata K, Asami S and Suzuki T: Different patterns in the induction of metallothionein mRNA synthesis among isoforms after acute ethanol administration. Biol Trace Elem Res 115: 147-156, 2007.

53. Pedersen MO, Larsen A, Stoltenberg M and Penkowa M: The role of metallothionein in oncogenesis and cancer prognosis. Prog Histochem Cytochem 44: 29-64, 2009.

54. Ning MS, Kim AS, Prasad N, Levy SE, Zhang H and Andl T: Characterization of the Merkel Cell Carcinoma miRNome. J Skin Cancer 2014; 289548, 2014.

55. Rojas F, Hernandez ME, Silva M, Li L, Subramanian S, Wilson MJ and Liu P: The oncogenic response to MiR-335 is associated with cell surface expression of membrane-type 1 matrix metalloproteinase (MT1-MMP) activity. PLoS One 10: e0132026, 2015.

56. Lu Y, Yang H, Yuan L, Liu G, Zhang C, Hong M, Liu Y, Zhou M, Chen F and Li X: Overexpression of miR-335 confers cell proliferation and tumour growth to colorectal carcinoma cells. Mol Cell Biochem 412: 235-245, 2016. 
57. Saumet A, Vetter G, Bouttier M, Antoine E, Roubert C, Orsetti B, Theillet $\mathrm{C}$ and Lecellier $\mathrm{CH}$ : Estrogen and retinoic acid antagonistically regulate several microRNA genes to control aerobic glycolysis in breast cancer cells. Mol Biosyst 8: 3242-3253, 2012.

58. Ruiz-Llorente L, Ardila-González S, Fanjul LF, MartínezIglesias $\mathrm{O}$ and Aranda A: microRNAs 424 and 503 are mediators of the anti-proliferative and anti-invasive action of the thyroid hormone receptor beta. Oncotarget 5: 2918-2933, 2014.

59. Wang Z, Zhang H, Zhang P, Li J, Shan Z and Teng W: Upregulation of miR-2861 and miR-451 expression in papillary thyroid carcinoma with lymph node metastasis. Med Oncol 30: 577, 2013.

60. Long C, Jiang L, Wei F, Ma C, Zhou H, Yang S, Liu X and Liu Z: Integrated miRNA-mRNA analysis revealing the potential roles of miRNAs in chordomas. PLoS One 8: e66676, 2013

61. Nakazawa K, Dashzeveg N and Yoshida K: Tumor suppressor p53 induces miR-1915 processing to inhibit Bcl-2 in the apoptotic response to DNA damage. FEBS J 281: 2937-2944, 2014.

62. Boo L, Ho WY, Ali NM, Yeap SK, Ky H, Chan KG, Yin WF, Satharasinghe DA, Liew WC, Tan SW, et al: MiRNA transcriptome profiling of spheroid-enriched cells with cancer stem cell properties in human breast MCF-7 cell line. Int J Biol Sci 12: 427-445, 2016.

63. Yang B, Jing C, Wang J, Guo X, Chen Y, Xu R, Peng L, Liu J and Li L: Identification of microRNAs associated with lymphangiogenesis in human gastric cancer. Clin Transl Oncol 16: 374-379, 2014.

64. Xu C, Zhang L, Li H, Liu Z, Duan L and Lu C: MiRNA-1469 promotes lung cancer cells apoptosis through targeting STAT5a. Am J Cancer Res 5: 1180-1189, 2015.

65. Yu CC, Chen YW, Chiou GY, Tsai LL, Huang PI, Chang CY, Tseng LM, Chiou SH, Yen SH, Chou MY, et al: MicroRNA let-7a represses chemoresistance and tumourigenicity in head and neck cancer via stem-like properties ablation. Oral Oncol 47: 202-210, 2011.

66. Molina-Pinelo S, Gutiérrez G, Pastor MD, Hergueta M, MorenoBueno G, García-Carbonero R, Nogal A, Suárez R, Salinas A, Pozo-Rodríguez F, et al: MicroRNA-dependent regulation of transcription in non-small cell lung cancer. PLoS One 9: e90524, 2014.

67. Ogony JW, Malahias E, Vadigepalli R and Anni H: Ethanol alters the balance of Sox 2, Oct4, and Nanog expression in distinct subpopulations during differentiation of embryonic stem cells. Stem Cells Dev 22: 2196-2210, 2013.

68. Zeineddine D, Hammoud AA, Mortada M and Boeuf H: The Oct4 protein: More than a magic stemness marker. Am J Stem Cells 3: 74-82, 2014

69. Liu CG, Lu Y, Wang BB, Zhang YJ, Zhang RS, Lu Y, Chen B, $\mathrm{Xu} \mathrm{H}$, Jin $\mathrm{F}$ and Lu P: Clinical implications of stem cell gene Oct-4 expression in breast cancer. Ann Surg 253: 1165-1171, 2011.

70. Liu C, Cao X, Zhang Y, Xu H, Zhang R, Wu Y, Lu P and Jin F: Co-expression of Oct-4 and Nestin in human breast cancers. Mol Biol Rep 39: 5875-5881, 2012

71. Leis O, Eguiara A, Lopez-Arribillaga E, Alberdi MJ, HernandezGarcia S, Elorriaga K, Pandiella A, Rezola R and Martin AG: Sox 2 expression in breast tumours and activation in breast cancer stem cells. Oncogene 31: 1354-1365, 2012.

72. Lengerke C, Fehm T, Kurth R, Neubauer H, Scheble V, Müller F, Schneider F, Petersen K, Wallwiener D, Kanz L, et al: Expression of the embryonic stem cell marker SOX2 in early-stage breast carcinoma. BMC Cancer 11: 42, 2011.

73. Jung JW, Park SB, Lee SJ, Seo MS, Trosko JE and Kang KS: Metformin represses self-renewal of the human breast carcinoma stem cells via inhibition of estrogen receptor-mediated OCT4 expression. PLoS One 6: e28068, 2011.

74. Hu J, Qin K, Zhang Y, Gong J, Li N, Lv D, Xiang R and Tan X Downregulation of transcription factor Oct4 induces an epithelial-to-mesenchymal transition via enhancement of $\mathrm{Ca}^{2+}$ influx in breast cancer cells. Biochem Biophys Res Commun 411: 786-791, 2011.

75. Trosko JE: From adult stem cells to cancer stem cells: Oct-4 Gene, cell-cell communication, and hormones during tumor promotion. Ann NY Acad Sci 1089: 36-58, 2006.

76. Wu F, Zhang J, Wang P, Ye X, Jung K, Bone KM, Pearson JD, Ingham RJ, McMullen TP, Ma Y, et al: Identification of two novel phenotypically distinct breast cancer cell subsets based on Sox2 transcription activity. Cell Signal 24: 1989-1998, 2012.

77. Nagata T, Shimada Y, Sekine S, Hori R, Matsui K, Okumura T, Sawada S, Fukuoka J and Tsukada K: Prognostic significance of NANOG and KLF4 for breast cancer. Breast Cancer 21: 96-101, 2014.
78. Machida K, Tsukamoto H, Mkrtchyan H, Duan L, Dynnyk A Liu HM, Asahina K, Govindarajan S, Ray R, Ou JH, et al: Toll-like receptor 4 mediates synergism between alcohol and $\mathrm{HCV}$ in hepatic oncogenesis involving stem cell marker Nanog. Proc Natl Acad Sci USA 106: 1548-1553, 2009.

79. Lewis-Wambi JS, Cunliffe HE, Kim HR, Willis AL and Jordan VC: Overexpression of CEACAM6 promotes migration and invasion of oestrogen-deprived breast cancer cells. Eur J Cancer 44: 1770-1779, 2008.

80. Ihnen M, Kilic E, Köhler N, Löning T, Witzel I, Hagel C, Höller S, Kersten JF, Müller V, Jänicke F, et al: Protein expression analysis of ALCAM and CEACAM6 in breast cancer metastases reveals significantly increased ALCAM expression in metastases of the skin. J Clin Pathol 64: 146-152, 2011.

81. Maraqa L, Cummings M, Peter MB, Shaaban AM, Horgan K, Hanby AM and Speirs V: Carcinoembryonic antigen cell adhesion molecule 6 predicts breast cancer recurrence following adjuvant tamoxifen. Clin Cancer Res 14: 405-411, 2008.

82. Blumenthal RD, Leon E, Hansen HJ and Goldenberg DM: Expression patterns of CEACAM5 and CEACAM6 in primary and metastatic cancers. BMC Cancer 7: 2, 2007.

83. Gomes IM, Maia CJ and Santos CR: STEAP proteins: From structure to applications in cancer therapy. Mol Cancer Res 10: 573-587, 2012.

84. Sano H, Wada S, Eguchi H, Osaki A, Saeki T and Nishiyama M: Quantitative prediction of tumor response to neoadjuvant chemotherapy in breast cancer: Novel marker genes and prediction model using the expression levels. Breast Cancer 19: 37-45, 2012.

85. Li CF, MacDonald JR, Wei RY, Ray J, Lau K, Kandel C, Koffman R, Bell S, Scherer SW and Alman BA: Human sterile alpha motif domain 9, a novel gene identified as down-regulated in aggressive fibromatosis, is absent in the mouse. BMC Genomics 8: 92, 2007

86. Stone A, Valdés-Mora F, Gee JM, Farrow L, McClelland RA, Fiegl H, Dutkowski C, McCloy RA, Sutherland RL, Musgrove EA, et al: Tamoxifen-induced epigenetic silencing of oestrogen-regulated genes in anti-hormone resistant breast cancer. PLoS One 7: e40466, 2012.

87. Cimino D, Fuso L, Sfiligoi C, Biglia N, Ponzone R, Maggiorotto F, Russo G, Cicatiello L, Weisz A, Taverna D, et al: Identification of new genes associated with breast cancer progression by gene expression analysis of predefined sets of neoplastic tissues. Int J Cancer 123: 1327-1338, 2008

88. Ito Y, Motoo Y, Yoshida H, Iovanna JL, Takamura Y, Miya A, Kuma K and Miyauchi A: Decreased expression of tumor protein p53-induced nuclear protein 1 (TP53INP1) in breast carcinoma. Anticancer Res 26B: 4391-4395, 2006.

89. Sorbello V, Fuso L, Sfiligoi C, Scafoglio C, Ponzone R, Biglia N, Weisz A, Sismondi P and De Bortoli M: Quantitative real-time RT-PCR analysis of eight novel estrogen-regulated genes in breast cancer. Int J Biol Markers 18: 123-129, 2003.

90. He X, Dong DD, Yie SM, Yang H, Cao M, Ye SR, Li K, Liu J and Chen J: HLA-G expression in human breast cancer: Implications for diagnosis and prognosis, and effect on allocytotoxic lymphocyte response after hormone treatment in vitro. Ann Surg Oncol 17: 1459-1469, 2010.

91. Jia Y, Liu H, Zhuang Q, Xu S, Yang Z, Li J, Lou J and Zhang W: Tumorigenicity of cancer stem-like cells derived from hepatocarcinoma is regulated by microRNA-145. Oncol Rep 27: 1865-1872, 2012.

92. Yin R, Zhang S, Wu Y, Fan X, Jiang F, Zhang Z, Feng D, Guo X and Xu L: MicroRNA-145 suppresses lung adenocarcinomainitiating cell proliferation by targeting OCT4. Oncol Rep 25: 1747-1754, 2011.

93. Xu N, Papagiannakopoulos T, Pan G, Thomson JA and Kosik KS: MicroRNA-145 regulates OCT4, SOX2, and KLF4 and represses pluripotency in human embryonic stem cells. Cell 137: 647-658, 2009.

94. Kozomara A and Griffiths-Jones S: miRBase: Integrating microRNA annotation and deep-sequencing data. Nucleic Acids Res 39 (Database): D152-D157, 2011.

95. Cicatiello L, Mutarelli M, Grober OM, Paris O, Ferraro L, Ravo M, Tarallo R, Luo S, Schroth GP, Seifert M, et al: Estrogen receptor alpha controls a gene network in luminal-like breast cancer cells comprising multiple transcription factors and microRNAs. Am J Pathol 176: 2113-2130, 2010.

96. Ali HO, Arroyo AB, González-Conejero R, Stavik B, Iversen N, Sandset PM, Martínez C and Skretting G: The role of microRNA-27a/b and microRNA-494 in estrogen-mediated downregulation of tissue factor pathway inhibitor $\alpha$. J Thromb Haemost 14: 1226-1237, 2016. 
97. Lee YM, Lee JY, Ho CC, Hong QS, Yu SL, Tzeng CR, Yang PC and Chen HW: miRNA-34b as a tumor suppressor in estrogendependent growth of breast cancer cells. Breast Cancer Res 13: R116, 2011.

98. Bhat-Nakshatri P, Wang G, Collins NR, Thomson MJ, Geistlinger TR, Carroll JS, Brown M, Hammond S, Srour EF, Liu Y, et al: Estradiol-regulated microRNAs control estradiol response in breast cancer cells. Nucleic Acids Res 37: 48504861, 2009.

99. Tan S, Ding K, Li R, Zhang W, Li G, Kong X, Qian P, Lobie $\mathrm{PE}$ and Zhu T: Identification of miR-26 as a key mediator of estrogen stimulated cell proliferation by targeting CHD1, GREB1 and KPNA2. Breast Cancer Res 16: R40, 2014

100. Liao XH, Lu DL, Wang N, Liu LY, Wang Y, Li YQ, Yan TB, Sun XG, Hu P and Zhang TC: Estrogen receptor $\alpha$ mediates proliferation of breast cancer MCF-7 cells via a p21/PCNA/ E2F1-dependent pathway. FEBS J 281: 927-942, 2014.

101. Zhang C, Zhao J and Deng H: $17 \beta$-estradiol up-regulates miR-155 expression and reduces TP53INP1 expression in MCF-7 breast cancer cells. Mol Cell Biochem 379: 201-211, 2013.

102. Masuda M, Miki Y, Hata S, Takagi K, Sakurai M, Ono K, Suzuki K, Yang Y, Abe E, Hirakawa $\mathrm{H}$, et al: An induction of microRNA, miR-7 through estrogen treatment in breast carcinoma. J Transl Med 10 (Suppl 1): S2, 2012.

103. Manavalan TT, Teng Y, Litchfield LM, Muluhngwi P, Al-Rayyan N and Klinge CM: Reduced expression of miR-200 family members contributes to antiestrogen resistance in LY2 human breast cancer cells. PLoS One 8: e62334, 2013.

104. Yu Y, Xiao CH, Tan LD, Wang QS, Li XQ and Feng YM: Cancerassociated fibroblasts induce epithelial-mesenchymal transition of breast cancer cells through paracrine TGF- $\beta$ signalling. Br J Cancer 110: 724-732, 2014.

105. Shibahara Y, Miki Y, Onodera Y, Hata S, Chan MS, Yiu CC, Loo TY, Nakamura Y, Akahira J, Ishida T, et al: Aromatase inhibitor treatment of breast cancer cells increases the expression of let-7f, a microRNA targeting CYP19A1. J Pathol 227 357-366, 2012.

106. Yu X, Zhang X, Dhakal IB, Beggs M, Kadlubar S and Luo D Induction of cell proliferation and survival genes by estradiolrepressed microRNAs in breast cancer cells. BMC Cancer 12: 29, 2012.

107. Cittelly DM, Das PM, Spoelstra NS, Edgerton SM, Richer JK, Thor AD and Jones FE: Downregulation of miR-342 is associated with tamoxifen resistant breast tumors. Mol Cancer 9: 317, 2010 .
108. Thornton JE and Gregory RI: How does Lin 28 let-7 control development and disease? Trends Cell Biol 22: 474-482, 2012.

109. Quann K, Jing Y and Rigoutsos I: Post-transcriptional regulation of BRCA1 through its coding sequence by the miR-15/107 group of miRNAs. Front Genet 6: 242, 2015.

110. Fu XM, Zhou YZ, Cheng Z, Liao XB and Zhou XM: MicroRNAs: Novel players in aortic aneurysm. Biomed Res Int 2015: 831641, 2015.

111. Gambari R, Brognara E, Spandidos DA and Fabbri E: Targeting oncomiRNAs and mimicking tumor suppressor miRNAs: New trends in the development of miRNA therapeutic strategies in oncology (Review). Int J Oncol 49: 5-32, 2016.

112. Wang H,Zhang P, Chen W, Feng D, Jia Y and Xie LX: Evidence for serum miR-15a and miR-16 levels as biomarkers that distinguish sepsis from systemic inflammatory response syndrome in human subjects. Clin Chem Lab Med 50: 1423-1428, 2012.

113. de Gonzalo-Calvo D, Davalos A, Montero A, GarciaGonzalez A, Tyshkovska I, Gonzalez-Medina A, Soares SM, Martínez-Camblor P, Casas-Agustench $\mathrm{P}$, Rabadán M, et al: Circulating inflammatory miRNA signature in response to different doses of aerobic exercise. J Appl Physiol 119: 124-134, 1985.

114. Rodosthenous RS, Coull BA, Lu Q, Vokonas PS, Schwartz JD and Baccarelli AA: Ambient particulate matter and microRNAs in extracellular vesicles: A pilot study of older individuals. Part Fibre Toxicol 13: 13, 2016.

115. Fabbri M, Paone A, Calore F, Galli R, Gaudio E, Santhanam R, Lovat F, Fadda P, Mao C, Nuovo GJ, et al: MicroRNAs bind to Toll-like receptors to induce prometastatic inflammatory response. Proc Natl Acad Sci USA 109: E2110-E2116, 2012.

116. Zhang L, Xu Y, Jin X, Wang Z, Wu Y, Zhao D, Chen G, LiD, Wang $\mathrm{X}, \mathrm{Cao} \mathrm{H}$, et al: A circulating miRNA signature as a diagnostic biomarker for non-invasive early detection of breast cancer. Breast Cancer Res Treat 154: 423-434, 2015.

117. Zhang Y, Zhang D, Wang F, Xu D, Guo Y and Cui W: Serum miRNAs panel (miR-16-2*, miR-195, miR-2861, miR-497) as novel non-invasive biomarkers for detection of cervical cancer. Sci Rep 5: 17942, 2015.

118. Zhao Q, Deng S, Wang G, Liu C, Meng L, Qiao S, Shen L, Zhang Y, Lü J, Li W, et al: A direct quantification method for measuring plasma MicroRNAs identified potential biomarkers for detecting metastatic breast cancer. Oncotarget 7: 21865-21874, 2016. 